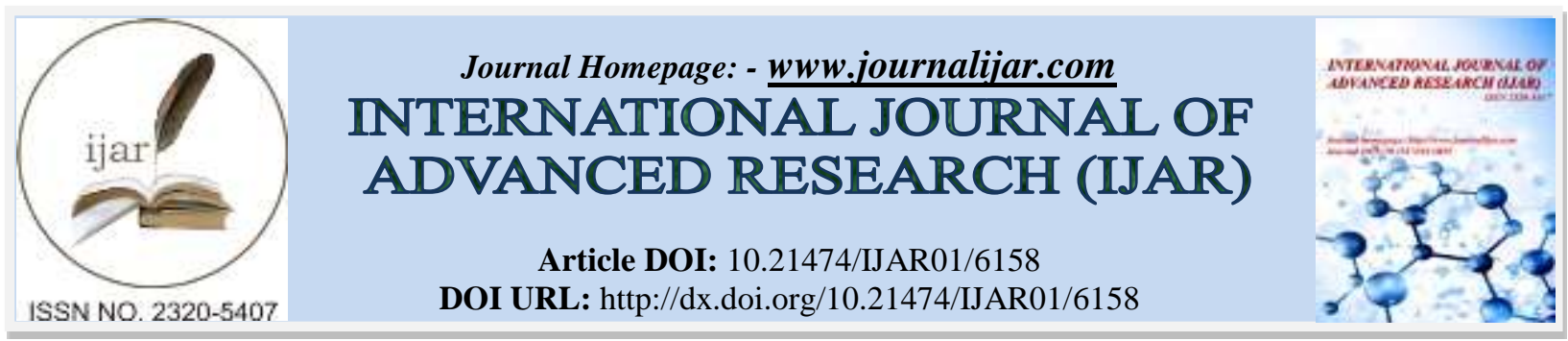

RESEARCH ARTICLE

\title{
DO THEY HAVE WHAT IT TAKES TO BE A SUCCESSFUL E-LEADER IN THE LEBANESE SMES?
}

Prof. Kamel Barbar.

Dean of Business School Jinan University- Lebanon.

\section{Manuscript Info}

..........................

Manuscript History

Received: 24 October 2017

Final Accepted: 26 November 2017

Published: December 2017
Abstract

Copy Right, IJAR, 2017,. All rights reserved.

\section{Introduction:-}

This research in this research grant is going to discover the competencies of successful e-leaders in the Lebanese SMEs. The focus will be on discovering how employees look at the the skills (know how), the knowledge (understanding content) and the attribute (personal traits) of $\boldsymbol{E}$ - Leaders in the Lebanese SMEs. The researcher in this study is interested in finding out to what extent do employees look at the leaders in the Lebanese SMEs to posses properties such as: Knowing the technology, Fast decision making, SWOT analysis, Making sense of the future, strategic planning and Attracting and retaining talent. The purpose of this research is to find out what are the new skills and competencies that managers need? How can you assess whether a manager has (or can develop) the right skills to thrive in e-business in Lebanon? To answer these questions, the researcher in this study interviewed over 479 employees in different Lebanese SMEs via well- constructed questionnaire, focusing on those who set strategic direction for e-business ventures as well as functional and business unit leaders responsible for implementing Web initiatives. Furthermore, Based on review of literature, it is found that managers must be able to communicate clearly, create effective processes, set performance goals, manage cross-functional teams and understand financial reports. The aim of this research is to find out if e-managers in the Lebanese SMEs need to develop new or stronger competencies! Somehow e-managers must develop new competencies . Working in the e-environment is challenging and managing there is even more so!

It is very important to know that the goals of leadership have not changed, but the new e-leader needs to implement those goals electronically on computer-mediated virtual teams that are dispersed over space and time.

What is very different is that the e-leader may never physically meet one or more of the followers, and that the main communication medium is the computer. The new paradigm provides a range of new opportunities: the ability to instantly communicate one-on-one with employees, customers, and suppliers; the capability to use talent wherever it exists; the opportunity to enhance organizational performance by assembling better multi-functional teams, improve better customer satisfaction; the ability to cut costs; and, scope for better knowledge management. These can positively impact an organization's competitive advantage.

However, e-leaders also have new challenges: how to bridge the physical distance from the followers; how to communicate effectively with far-flung team members; how to convey enthusiasm and inspire followers electronically; how to build trust with someone who may never see the leader; and so on. 
At a time when companies are increasingly relying on information and communication technology (ICT) to come up with innovations both on the management side and in products and services, the strategic role of IT Managers and computer departments is expanding rapidly. This is giving rise to an increasing demand for 'e-leaders' - who need to master both company management skills and expertise in the ICT field. The challenge facing many company bosses nowadays is to be able adapt their leadership approach to the new rules and new codes of the digital era.

First of all, e-leadership doesn't just mean you own the latest version of the iPhone, nor that you have computer programming skills. E-leaders need a T-shaped portfolio of skills, i.e. vertical as well as horizontal. On the horizontal plane, company top management must be capable of building relations across boundaries, managing change and developing a global strategic vision, and also able to experiment and innovate. On the vertical axis, they must have among their skill sets ICT expertise, product expertise and customer-relations expertise. True e-leaders should for instance be right up-to-date on the company's latest investment in Information and Communication technology, and must be able to grasp not only the economic and managerial benefits which it will bring but also the potential risks.

At the same time, the use of social networks has become an integral part of the e-leader's role, as evidenced by Pascal Dasseux, COO of Havas Media, who explained: "I use Twitter as a 'smart filter' so that I only spend time on information that really interests me." Alexandre Matsch, founder and CEO of Melty Group - a 'news network aimed at Generation Y' - said that he had even agreed business contracts with shareholders on the social networks. "We're increasingly moving towards multi-channel communication, and social networks will become essential collaboration tools in the same way as old-fashioned messaging has been," he predicted. Moreover, on his personal facebook page, Matsch's subscribers regularly see posts relating to his private life. "People who are interested in the Melty adventure might also be interested in my own personal story, which helps to give a human face to the company I cofounded," he explains.

\section{Purpose of the Study:-}

The purpose of this research is to understand:

1. What e-leadership style does/would make a difference to the success of the organization?

2. If organization success is not driven by e-leadership style (in this case, situational leadership style), then what drives the success of the organization?

3. Could factors such as ability to communicate clearly, creating effective processes, setting performance goals, managing cross-functional teams, and understanding financial reports affect the success of the organization

4. more than the competencies of e-leadership such as Knowing the technology, Fast decision making, Partnering, Making sense of the future, Staying focused and Attracting and retaining talent?

\section{Statement of the Research Problem and Significance of the Study:-}

Is to answer the big question on what are the competencies of successful e-leaders in the Lebanese SMEs and how employees perceive it?

The study conducted is recommended by experts. Princely Ifinedo, (2011) recommended that Policy makers, industry leaders, and small business operators wishing to understand some of the reasons why certain SMEs in the country lag in the adoption of IEBT and related technologies can benefit from the information provided in his study.

Joel Indrupati and Tara Henari, 2010, conducted a research paper to evaluate the effectiveness of online social networking by entrepreneurs in the Arabian Gulf recommended that with the rise in the use of social networking, entrepreneurs can now target their markets using online social networks. Social networking web sites allow businesses to introduce their products to specific market segments, with low expense, and with a low chance of failure. This rising phenomenon of web-based social interaction can change the way businesses operate in future.

\section{Research Specific Questions:-}

1. What is the relation between size of SME and E-Leadership?

2. What is the relation between type of SME and E-Leadership?

3. What is the relation between E-Leadership and employees empowerment?

4. What is the relation between E-Leadership and strategic innovation? 


\section{Significance of the Study:-}

The significance of the study is based on review of literature. This study on "Do they have what it takes to be a successful e-Leaders in the Lebanese SMEs?" will show that a variety of competencies that affect leaders in order for them to become E-Leaders. It can be said: show me innovation, show me respect and show me information and fast decision ... or show me the door! This study should give implications for decision making, policy making and recommendations for further research. Research Hypotheses

\section{Statement of the Research Hypotheses:-}

The revercher in this study is interested in testing the following hypotheses :

1. E-Leaders are more able to set strategic plans than other leaders.

2. E- Leaders are more able to stimule the dissemination of information among lower level management and to enhance idea generation.

3. If E-Leaders always look for ways to do things better and improve results then, it stimulates lower level managements to do the same as a result of role-modeling and application behavior

4. E- Leaders in the SMEs do better SWOT analysis, recruit employees and retain employees better than others..

5. E- Leaders in the SMEs are more able to provide their employees with a sense of direction as well as some general guidelines than non E-Leaders.

\section{Review of literature:-}

Drucker (1985, p. 32) states that: "innovation is the specific tool of entrepreneurs". Braczyk et al. (1998) indicate that understanding of "E- learning and innovation" is essential. This understanding is seen as vital if more localized and specific interventions are to be made beyond those of "national systems of innovation". There is a need to clarify how SMEs can overcome the innate barriers of their leaders to implement innovation practice, by focusing on E- Environment within SMEs (Teece, 1996). Teece argues that there is a need to focus on "the firm" within EEnvironment if substantial improvements in innovation are to be obtained. One way for organizations to become more innovative is to capitalize on their E-leaders' ability to improve their employees' ability to innovate. Many practitioners and academics now endorse the view that E-Leaders help to attain organizational success (Van de Ven, 1986; Amabile, 1988; Axtell et al., 2000; Smith, 2002; Unsworth and Parker, 2003). In order to realize a continuous flow of innovations, employees need to be both willing and able to innovate. E- leaders are central to innovation and central to several well-known management principles, including total quality management (McLoughlin and Harris, 1997; Ehigie and Akpan, 2004), continuous improvement schemes (Boer and Gieskes, 1998).

Current scholarship of e-leadership says the goals of leadership have not changed, but the new e-leader needs to implement those goals electronically on computer-mediated virtual teams that are dispersed over space and time. What is very different is that the e-leader may never physically meet one or more of the followers, and that the main communication medium is the computer. The new paradigm provides a range of new opportunities: the ability to instantly communicate one-on-one with employees, customers, and suppliers; the capability to use talent wherever it exists; the opportunity to enhance organizational performance by assembling better multi-functional teams, and to improve better customer satisfaction by using the -follow the sunll methodology; the ability to cut costs; and, scope for better knowledge management. These can positively impact an organization's competitive advantage.

In order to study the successful e-leaders in Lebanon in small and medium enterprises, a literature review was done. Six studies from different countries were summarized below.

The article done by Ismail Sila and Dawn Dobni, (2012) identify the B2B e-commerce (B2BEC) usage patterns of North American small- and medium-sized enterprises (SMEs) in their supply chains, the contextual factors that influence usage patterns, and the subsequent effects of these patterns on firm performance. Technologyorganization-environment (TOE) frameworks and inter-organizational factors provide a valid theoretical guideline to study firms' B2BEC usage patterns.

Ismail Sila and Dawn Dobni distinguished three distinct types of B2BEC usage patterns - E-Limiteds, E-Leaders, and E-Laggards - emerged. Higher levels of B2BEC usage result in stronger firm performance. In light of the potential performance improvements that B2BEC adoption offers, managers should assess the risks associated with maintaining their current speed of e-business deployment versus the risks associated with escalating it. 
The article of Princely Ifinedo, (2011), The Discussion is related is to what causes Canadian small and medium-size enterprises (SMEs) to be reticent about accepting internet and e-business technologies (IEBT) in their operations. Princely findings indicated that perceived benefits, management commitment/support, and external pressure are significant predictors of IEBT acceptance in the sampled SMEs; the results did not show that organizational IT competence, IS vendor support, and availability of financial support positively influence IEBT acceptance in the sampled SMEs. Princely noticed that Policy makers, industry leaders, and small business operators wishing to understand some of the reasons why certain SMEs in the country lag in the adoption of IEBT. The study also alerted the attention of local IS vendors and financial institutions to what can be done to strengthen IS adoption in Canadian small businesses.

The article done by Geoffrey J. Simmons, Mark G. Durkin, Pauric McGowan and Gillian A. Armstrong, (2007) identify the Determinants of internet adoption by SME agri-food companies. The study utilizes and tests a conceptual framework derived from the extant literature in relation to the determinants of SME web site adoption and utilization of 50 Northern Ireland SME agri-food companies. The most important findings of their study are

1. There is a need for SME agri-food companies to develop an awareness of the internet's efficacy for their business

2. The need for a subsequent dynamic strategic approach in adoption and utilization.

3. The lack of marketing ability and negative industry norms prevalent within developed economy agri-food industries will contribute negatively to internet adoption and utilization.

4. The importance of marketing ability and industry norms in relation to their impact on the central determinants of internet adoption by the SME agri-food companies studied.

5. The research findings support the conceptual framework's usefulness as a research tool.

Joel Indrupati and Tara Henari, 2010, conducted a research paper to evaluate the effectiveness of online social networking by entrepreneurs in the Arabian Gulf. It is a descriptive research conducted by interviewing a number of entrepreneurs in the Arabian Gulf who use online social networks as a method of promoting their products. Joel Indrupati and Tara Henari found that social networking is a cheap and easy method of advertising and gives all entrepreneurs a better chance of reaching their target market and, thereby, in succeeding in their ventures.Social networking web sites allow businesses to introduce their products to specific market segments, with low expense, and with a low chance of failure.

Nancy M. Levenburg, 2006, conducted a study titled "Benchmarking customer service on the internet: best practices from family businesses". This study purports to examine the practices of service sector market leaders and measure performance results of adopting selected customer service applications. The aim was to identify inspirational targets and internet applications benchmarks among family owned businesses since for them, the importance of reputation may well hinge on providing outstanding customer service to the local community. A six-page self-administered survey questionnaire was used to collect data from 374 family firms in West Michigan. Nancy M. Levenburg suggested that while over 75 percent of firms use e-mail to communicate with current customers and for customer service purposes, what distinguishes best practices is e-mailing with prospective customers, targeting small or hardto-reach markets, and adopting more sophisticated applications, including online product demonstration, ordering, delivery, and order tracking.

A. Gunasekaran and E.W.T. Ngai, 2005, conducted a study titled "E-commerce in Hong Kong: an empirical perspective and analysis". The main objective of this study is to develop a framework for: identifying the reasons for using e-commerce; understanding the implications of e-commerce in companies; and implementing and applying ecommerce successfully for improved organizational competitiveness and success. Based on the feedback from the pilot-test, the questionnaire was modified and a final questionnaire was developed and mailed to companies in Hong Kong. In the survey, conducted with Hong Kong companies, the perceived benefits and perceived barriers of ecommerce implementation are discussed.

A.Gunasekaran and E.W.T. Ngai found that the major factors that influence the application and implementation of e-commerce are: perceived usefulness of web; perceived barriers of the internet for e-commerce; usage of the internet; and perceived benefits of the internet for e-commerce. In addition to this, country-specific factors such as culture, technology competency, government policy, educational level, influence the level of application of ecommerce. 
The term leadership means different things to different people. Although no ultimate definition of leadership exists (Yukl, 2002), the majority of definitions of leadership reflect some basic elements, including "group" "influence" and "goal" (Bryman, 1992). We think of leadership as the process of influencing others towards achieving some kind of desired outcome.

Leadership research has taken different perspectives, leader traits, behaviours, and the influence of situational characteristics on leader effectiveness, for example, have all been studied. In the past 20 years, transformational and charismatic leadership approaches have gained in popularity (Den Hartog and Koopman, 2001). We limit ourselves to the behavioral perspective and address how leader behavior influences employees' idea generation and application behavior. Although the impact of leaders seems intuitively appealing, most behavioral leadership studies look at performance or effective outcomes rather than innovation-related outcomes.

Available research on the relationship between leader behavior and individual innovation has investigated transformational leadership, participative leadership, and leader-member exchange (LMX) theory. Transformational leadership is hypothesized to encourage creativity (Kahai et al., 2003; Shin and Zhou, 2003). As transformational leaders stimulate followers to view problems in new ways and help them to develop to their full potential, this is likely to result in the enhanced creativity of followers. However, previous studies show mixed results. Kahai et al. (2003) used an electronic meeting system with students in a laboratory experiment to investigate the impact of leadership, anonymity and rewards on creativity-relevant processes and outcomes. As a by-product they found a positive impact of transformational leadership. However, an experiment by Jaussi and Dionne (2003) found little effect of transformational leadership on creativity. In contrast, field research by Shin and Zhou (2003) in Korea showed that transformational leadership was positively related to follower creativity.

Participative leadership involves the use of various decision-making procedures that determine the extent to which people can influence the leader's decisions and have the autonomy to design and perform their own tasks. Participative leadership can take different forms, including consultation, joint decision making and delegation (Yukl, 2002). Such leadership has been identified as an antecedent of individual innovation. Judge et al. (1997), for example, interviewed R\&D managers, scientists, and technicians from new biotechnology firms and concluded that giving employees operational autonomy encouraged an innovative culture. In a study among the employees of a manufacturing plant, Axtell et al. (2000) found a positive relationship between participation and employees' innovative behavior, measured using self-ratings of employees' suggestions and implementation efforts. Similarly, Frischer (1993) found that when product-development managers gave authority to their subordinates and provided them with a sense of responsibility, subordinates were aware of a positive innovation climate.

LMX theory focuses on the social exchange relationships between leaders and employees. It proposes that the quality of the relationship between a leader and follower influences outcomes such as subordinate satisfaction, supervisor satisfaction, performance, commitment, role conflict, role clarity and turnover intentions (Yukl, 2002). Some suggest that the quality of the relationship between a leader and follower is also related to innovativeness (Graen and Scandura, 1987). High-quality exchange relationships include providing employees with challenging tasks, support in risky situations and the provision of task-related resources and recognition, all facilitating individual innovation. In line with this, Tierney et al. (1999) found a positive relationship between high-quality relationships and creativity in a study among R\&D leaders and employees of a chemical firm. Janssen and van Yperen (2004) also found that high-quality relationships had a positive impact on the broader construct of innovative behavior.

There are various views as to how leadership differs from management and entrepreneurship. Leadership is seen as a subset of managerial activities, others see leading and managing as overlapping roles, yet others describe them as different processes. For example, Kotter (1990) differentiates their intended outcomes: management seeks to produce predictability and order, while leadership aims to produce change. In Kotter's view, leaders and managers are not necessarily different persons, but rather different roles. This also holds for entrepreneurship. For example, when organizations grow beyond a few employees, entrepreneurs (should) start worrying about how followers must be directed towards specific goals (Shane, 2003). In this study, entrepreneurship, management and leadership are roles that are not mutually exclusive. Most of our interviewees fulfilled all three roles, including being a leader as part of their work. They are also managers and most were the entrepreneurs that started their firm. We thus use "leader" "manager" and "entrepreneur" interchangeably in referring to the interviewees. 


\section{Leadership and leadership style:-}

According to Dainty and Anderson (1996, p. 116) who quote Burns (1978) "Leadership is one of the most observed and least understood phenomena on earth." There is no universal leadership definition or style due to "innumerable situational and contextual factors" (Lord et al., 2001, p. 311). The topic is viewed and researched from many perspectives and continues to draw the focus of scholars and management training professionals. Yammarino et al. (2001) discussed leadership as a multilevel process that may encompass numerous perspectives, all of which should be considered in an effort to understand the complex nature of leadership. Traditionally leadership research is primarily based on classic bi-factorial models such as task and relation-oriented leadership (Gil et al., 2005) but in the last three decades "new paradigms" such as charismatic leadership (House, 1977), transactional leadership (Bass and Avolio, 1993), transformational leadership (Bass and Avolio, 1993), visionary leadership (Westley and Mintzberg, 1989) and new leadership (Bryman et al., 1996) have emerged. This study is based on a recent model of leadership with two styles of leadership described as transactional and transformational leadership that can be objectively and consistently measured.

\section{Transformational e- leadership:-}

This is a transformational e- leadership which is the same as transformational leadership that motivates followers by appealing to higher ideals and moral values which can inspire employees to perform beyond expectations and transform both individuals and organizations (Bass, 1985).

Bass (1985) asserted that transformational leadership would result in followers performing beyond expected levels of performance as a consequence of the leader's influence. The underlying influence process is described in terms of raising an awareness of the importance and value of designated outcomes and by developing intellectually stimulating and inspiring followers to transcend their own self-interests for a higher collective purpose, mission or vision. Rouche and colleagues (1989) defined transformational leadership in terms of the ability of a leader to influence the values, attitudes, beliefs, and behaviors of others by working with and through them in order to accomplish the organization's mission and purpose. Hater and Bass (1988) state:

The dynamics of transformational leadership involve strong personal identification with the leader, joining in a shared vision of the future, or going beyond the self-interest exchange of rewards for compliance (Hater and Bass, 1988, p. 695).

Bass' (1995) definition of transformational leadership has four dimensions:

Charisma. The leader provides vision and a sense of mission; instills pride, faith and respect; excite, arouse and aispire their subordinates.

Individual consideration. The leader provides coaching and teaching; delegates projects to stimulate learning experiences; provides for continuous feedback; and treats each follower as an individual.

Intellectual stimulation. The leader provides subordinates with a flow of challenging new ideas; motivates followers to think in new ways: emphasizes problem solving and the use of reasoning before taking action.

Inspiration. The leader acts as a model for subordinates; behaves in ways that motivate and inspire followers by providing meaning and challenge; communicates a vision.

Transformational leaders were shown to have subordinates, who report greater satisfaction and more often exert extra effort, and to have higher performing work groups and receive higher ratings of effectiveness and performance (Bryman, 1992; Bass, 1995).

Based on the definitions of transformational leadership, we can suggest that transformational leaders create a dynamic organizational vision that often necessiates a metamorphosis in cultural values to reflect greater innovation. We can also propose that transformational behaviors on the part of leaders promote empowering cultural norms.

\section{What is Transformational e-Leadership:-}

The theory and studies about transformational e- leadership is the same as transformational leadership and were started by Burns (1978). It was based on the idea that such type of leadership would raise the motivation and morale of both the leader and the subordinate. Leadership related studies shifted from traditional and transactional model to the newer concept of transformational leadership. Transformational leadership is much studied in comparison to transactional leadership. Transactional style of leadership is defined by the exchange between the superior and the subordinate. For example, a manager rewards his subordinate by giving a raise for doing a better job. In this case, both the leader and the subordinate are dependent on each other and the contributions of each side is understood and rewarded (Burns, 1978). 
On the other hand, transformation leadership has to do with deeper values such as justice and integrity. By these values, transformational leaders unite their followers and have the ability to change their goals and beliefs. Leaders and followers engage in such a way that raises one another motivation and morale (Burns, 1978) therefore reaching higher levels of performance than previously thought possible (Bass, 1990). Transformational leaders subordinates report greater satisfaction and exert extra effort and receive higher ratings of effectiveness and performance (Bryman, 1992; Bass, 1995). Transformational Leadership theory had become one of the major leadership theories in the organizational behavior field over the past 20 years (Lim and Ployhart, 2004).

\section{History of Transformational Leadership:-}

Humphreys and Einstein (2003) argue that although it is a relatively recent conceptual model, transformational leadership components, factors and behaviors were certainly present in earlier thoughts and models. Early Greek philosophers were promoting charismatic leaders as moral agents that inspire followers evoking symbolic images and expressing important ideas in simple rational ways. Also transformational leadership glimpses are found in the writings of early management pioneer Frederick Taylor: "It becomes the duty of those on the management side to deliberately study the character, the nature, and the performance of each workman." Giving many other examples, Humphrey and Einstein (2003) conclude that the roots of transformational leadership model are inextricably embedded in the evolution of management thought.

\section{Dimensions of Transformational Leadership:- \\ Bass (1995) defined four dimensions for transformational leadership:-}

Charisma: The leader provides vision and sense of mission instilling pride and faith, and gaining respect and trust therefore exciting, arousing and aspiring subordinates.

Individual Consideration: Transformational leaders pay close attention to differences between subordinates, provide coaching, teaching and delegation to stimulate learning and experience and treats each follower as an individual.

Intellectual Stimulation: The leader provides challenging new ideas and motivates subordinates to think in new and different ways therefore promoting intelligence, rationality, logical thinking and careful problem solving.

Inspiration: Inspiration is a companion or charisma. Leader acts as a model to follow and behaves in ways that motivate and inspire followers by providing meaning and challenge.

\section{e-Leader-member exchange (LMX):-}

Gerstner and Day (1997) argued that transformational leadership seems conceptually similar to the process of developing a unique exchange relationship that is central to leader-member exchange (LMX). According to LMX theory, leaders and followers develop dyadic relationships and leaders treat individual followers differently, resulting in two groups of followers-an in-group and an out-group. The in-group consists of a small number of trusted followers with whom the leader usually establishes a special higher quality exchange relationship. The outgroup includes the remaining followers with whom the relationship of the leader remains more formal. These varying social exchange relationships are relatively enduring and they develop owing to the leader's limited time and energy, and inability to give equal attention to all followers (Gerstner and Day, 1997).

\section{LMX and transformational e-leadership:-}

LMX is conceptually described as an exchange process, making it appear to be a transactional leadership model, but it is not usually measured this way. Members of the in-group are not told what is expected in return for the rewards they are given as part of a high-quality exchange. Since leaders do not make explicit demands on in-group members in the form of harder work for these rewards, the relationship might be better characterized as transformational. Palmer et al. (2001) found that transformational leadership was positively related to the ability to monitor and manage emotions in oneself and others. To the extent that LMX measures tap mutual respect, trust, and the overall quality of the working relationship, LMX is oriented toward transformational leadership.

\section{Influence strategy and transformational e-leadership:-}

The distinguishing feature of transformational leaders is that they are held in high regard and respected by their followers. Dvir et al. (2002) found that transformational leadership enhanced direct followers' development and indirect followers' performance. The shared perspective of the transformational leader's idealized vision and its potential for satisfying followers' needs make the leader likable. The personalized relationship between 
transformational leader and followers creates an environment in which the followers would feel comfortable to reason and argue with the leader. The transformational leaden is an ideal or a role model for the follower, and hence the follower would not be inclined to take any issue to those in the hierarchy who are at a higher level than the transformational leader.

\section{Emotional intelligence:-}

Mandell and Pherwani (2003) found that more adaptive emotional functioning, operationalised as emotional intelligence, predicted a higher level of transformational leadership. It may be that emotional intelligence provides a foundation on which transformational leadership behaviors can build. The four-branch model of emotional intelligence (Mayer et al., 2004) proposes that emotional intelligence consists of the interrelated functions of: perception of emotion in the self and others; using emotion to facilitate decision making; understanding emotion in the self and others; and managing emotion in the self and others.

\section{Self-efficacy:-}

Self-efficacy is the cognitive process by which a person evaluates his or her ability to perform a certain task (Bandura, 1997). Bandura (1994) defined self-efficacy as individuals' beliefs about their "capabilities to produce designated levels of performance that exercise influence over events that affect their lives. Self-efficacy beliefs determine how people feel, think, motivate themselves and behave" (p. 78). Higher self-efficacy has been found to be associated with good outcomes in a variety of realms of life (Bandura, 1997), including greater job satisfaction and better work performance (Judge and Bono, 2001).

According to Bandura $(1986,1997)$ the following four factors determine the level of an individual's self-efficacy beliefs in a given realm of life:

Personal mastery experiences.

Vicarious mastery experiences.

Verbal persuasion.

\section{Physiological and affective states.:-}

Leaders' needs-supplies fit will be positively related to followers' perceptions of transformational leader behaviors For individuals in leadership positions, those who consider themselves to be a better fit with their leadership roles believe that they have the capacity required to be effective leaders. This perception is likely to be related to higher levels of leader self-efficacy. As can be developed via self-efficacy theory (Bandura, 1986), leaders will be more motivated to display inspirational and developmental behaviors if they feel that their own abilities are a good fit with their leadership role. As such, leaders who feel that they possess the KSAs needed for their leadership roles are more likely to demonstrate positive leader behaviors such as those of transformational leaders. Further, Edwards and Shipp (2007) argued that there is a link between demands-abilities fit and task performance because high levels of demands and abilities refer to situations where a leader would be challenged with high demands but possesses the strong abilities to meet those demands. Therefore, leaders are expected to have stronger task performance and engage in more transformational leader behavior (such as communicating their values, challenging subordinates to exceed expectations, inspiring them to join the collective vision of the organization, and providing developmental opportunities) if they perceive that they have the ability to meet these demands of the leadership role. Furthermore, when the situation demands change and the leader feels able to meet this demand, transformational leadership will be especially relevant. Crisis, uncertainty, and turbulence all make transformational leadership more likely (Bass, 1985; House, 1995). In these situations, leaders need to produce change and movement, establish direction, align people, as well as motivate and inspire followers (Kotter, 1990).

Leaders' demands-abilities fit will be positively related to followers' perceptions of transformational leader behaviors

The benefits of transformational leadership extend beyond followers to supervisors' perceptions of leader effectiveness. By aligning follower values with the organization's values and motivating followers to perform beyond expectations, transformational leaders increase organizational goal accomplishment, thus increasing how they will be perceived in terms of leader effectiveness (Bass, 1985; Shamir et al., 1993). Transformational leaders have been shown to put forth more effort and receive higher performance evaluations (Bass, 1985). 
Supervisory perceptions of a leader's effectiveness should align with followers' perceptions of transformational leadership. If followers are happy with their leaders and performing well, their team performance levels will likely also be strong, thus making it probable that supervisors will rate the leaders as effective

\section{Gender and e-leadership:-}

The gender-centered perspective proposes that women develop a feminine style of e-leadership and men adopt a masculine style of leadership (Eagly et al., 1992). According to social role theory individuals behave in accordance with societal expectations of the gender role (Eagly, 1987). The structural perspective emphasizes an organization's expectations, and proposes that people behave according to these expectations and gender has no effect (Eagly et al., 1992; Kanter, 1977). Lastly, the fit between leadership position and gender has been suggested to have an impact. For example, military leadership positions are defined in more masculine terms than feminine (Eagly et al., 1995).

Effective e-leadership has been perceived to require traits stereotyped as masculine (e.g. Brenner et al., 1989; Schein, 1973a, b, 1975; Powell and Butterfield, 1979, 1984, 1989), but recent leadership literature has stressed more feminine behavior. Masculine traits are typically employed in the initiation of structure, whereas feminine traits are more employed in demonstrating consideration (Spence and Helmreich, 1978; Williams and Best, 1982). Initiation of structure consists of the behavior of setting and defining goals, structuring and defining work behavior and maintaining a strong task orientation. Consideration includes showing concern for subordinates' feelings, participation, satisfaction and friendship. Men have been found to be somewhat more self-assertive, aggressive and coarse in their manner and language than women. Women, in contrast, have been found to be more expressive of emotion and compassion (Chesler, 2001; Simmons, 2002). It has been found that feminine leadership qualities are more highly valued by subordinates, while masculine qualities are more valued by managers (Cann and Siegfried, 1987). TF-leadership consists of both feminine and masculine qualities, the feminine consist of behavior connected with encouraging, rewarding and enabling others, and the more masculine are connected with visioning and challenging.

\section{Motivation by e- leader:-}

When going through the process of human learning, motivation is considered a central element. The knowledge within the organization will not reach the maximum if the organization does not possess the ability to motivate its employees. Therefore, it becomes the aim of every learning organization to find the factors that enable it to motivate its employees to continuous learning and to take advantage of this knowledge to ensure its living (Islam et al., 2008) The term motivation is derived from the Latin word "movere" which means to move. Islam et al. (2008) stated that motivation is what moves us from boredom to interest. It is like the steering wheel of a vehicle that directs our activities. Motivation represents those psychological processes that cause the arousal, direction, and persistence of voluntary activities that are goal oriented. Motivation is a force that energizes behavior, gives direction to behavior, and underlies the tendency to persist. Based on what have been mentioned, individuals must be sufficiently stimulated and energetic, must have a clear focus on what is to be achieved, and must be willing to commit their energy for a long enough period of time to realize their aim in order to achieve goals. Since, a leading function of management involves influencing others to work toward organizational goals, motivation is an important aspect of that function.

\section{Types of Motivation by e- leader:-}

Islam et al. (2008) link intrinsic motivation to socialization into social work values and norms with respect to the main organizational applications of intrinsic motivation, namely cognitive evaluation theory and job characteristic theory. They suggest that societal values and norms which are adopted by individuals and that support productive work behavior could contribute to intrinsic work motivation beyond what these theories would predict. Ground workers, library clerks, patient relation representatives, and medical record assistants are four types of employees the authors have surveyed at East Carolina University to know their motivation; they found that good pay and recognition were the most effective motivators, whereas benefits, working environment, co-workers weren't as effective as the previous two. The programs adopted at Eastman Chemical Company to motivate and retain its employees includes job security, performance-based appraisal system, extrinsic recognition through employee suggestion system, giving performance feedback, training in problem solving, etc. The authors found that the ranking of ten motivational factors made by the supervisors are significantly different to those made by the employees. Therefore, managers shouldn't think that what will motivate them will also motivate the employees.

Eskildsen et al. (2003) studied the differences in intrinsic work motivation and job satisfaction among employees with different characteristics working in Nordic countries. The authors found that job satisfaction and intrinsic work 
motivation have a nearly linear relationship with age and that the employees with higher education reported higher level of intrinsic work motivation.

The three factors that play as motivators to the knowledge workers working in the Japanese financial sector are monetary incentive, human resource development, and job autonomy. (Islam, 2008)

\section{Theories of employee motivation by e- leader:-}

The major theories in motivation are classified into three categories: needs theory, cognitive theory, and reinforcement theory. The most popular needs theory is owing to Abraham Maslow and it is known as Maslow's motivation theory of hierarchical needs. The hierarchy includes five basic levels of needs, which should be satisfied consecutively. ERG theory proposed by Alderfer is an alternative to Maslow's theory in which he consolidated five levels of Maslow's hierarchy into three levels: existence (E), relatedness (R), and growth (G). Existence needs include physiological factors such as food, shelter, clothes, good pay, fringe benefits, good working conditions, etc. Relatedness needs address our relationship with others such as families, friends, work groups, etc. Growth needs are associated with Maslow's last two levels, i.e. self-esteem and self-actualization. (Islam et al., 2008)

Herzberg developed the 2-factor (motivators and hygiene factors) theory in employee motivation. He argued that eliminating the cause of dissatisfaction (through hygiene factors) would not result in a state of satisfaction; rather, the use of motivators will lead to satisfaction (or motivation).

Expectancy theory, one of the best known cognitive theories, originally proposed by Vroom argues that the strength of a tendency to act in a certain way depends on the strength of an expectation that the act will be followed by a given outcome and on the attractiveness of that outcome to the individual.

Equity theory implies that individuals are not just concerned with the absolute amount of benefits they receive for their efforts, but also with the relationship of this amount to what others receive. Based on one's inputs, such as effort, experience, education, and competence, one can compare outcomes such as pay, recognition and other factors. If there is imbalance in the outcome-input ratio people receive relative to others, tension will emerge. Equity theory is based on three main assumptions. First, the theory holds that people develop beliefs about what constitutes a fair and equitable return for their contributions of their jobs. Second, the theory assumes that people tend to compare what they perceive to be the exchange they have with their employers. The other assumption is that when people believe that their own treatment is not equitable relative to the exchange they perceive others to be making, they will be taking actions that they deem appropriate.

According to the goal-setting theory, people will be motivated if they are provided with a goal followed by a reward. The goals should be specific and measurable, challenging but attainable, relevant to the organization and must be accomplished within a specific period of time. It is usually considered as a powerful motivational tool.

The reinforcement theories, proposed by B.F. Skinner, are actually the antithesis of cognitive theories in the sense that the theories do not relate with human thought process. According to the reinforcement theory, it is not necessary to look for cognitive explanations, since our behavior can be explained by consequences in the environment. Instead, the theory depends on the law of effect which states that behaviors having pleasant or positive consequences are more likely to be repeated and behaviors having unpleasant or negative consequences are less likely to be repeated. (Islam et al., 2008)

\section{Motivation and hygiene factors by e- leader:-}

Herzberg developed two distinct lists of factors in his inquiry about the attitudes of employees. One set of factors caused happy feelings or a good attitude within the worker, and these factors, on the whole, were task-related. The other set, which is not directly related to the job itself but to the conditions while doing that job, is evident where there are feelings of unhappiness or bad attitude. (Tietjen et al. 1998)

The first group he called motivators (job factors):

1. Recognition;

2. Achievement;

3. Possibility of growth;

4. Advancement; 
5. Responsibility;

6. work itself.

The second group Herzberg named hygiene factors (extra-job factors):

1. Salary;

2. Interpersonal relations - supervisor;

3. Interpersonal relations - subordinates;

4. Interpersonal relations - peers;

5. Supervision - technical;

6. Company policy and administration;

7. Working conditions;

8. Factors in personal life;

9. Status;

10. Job security.

Motivators refer to factors intrinsic within the work itself like the recognition of a task completed. Conversely, hygienes tend to include extrinsic entities such as relations with co-workers, which do not pertain to the worker's actual job.

\section{Procedures and Methodology:-}

Population and sample Selection:-

Our main target or segment is the leaders in general including all middle and top management. A well constructed questionnaire will be distributed to a big sample size 600 managers at all levels in the Lebanese SMEs. The researcher collected back 479 questionnaires that were valid for analysis from the selected 600 sample for the study .

\section{Questionnaire:-}

The questionnaire will be basically constructed according to the theories and concepts of E-Leaders and the competencies of E-Leaders mentioned in this proposal.. The researcher in this study will construct approximately Likert- Type questions on a scale ranging from 1 "SD" to 5 "SA". The researcher in this study will depend on trained interviewers to collect data and on statistician to use SPSS to analyze the data.

\section{Questionnaire:-}

In this section, there are several statements about e-leader. For each statement, indicate if you agree or disagree with the statement based on a 5 point scale where " 1 " means Strongly Disagree and "5" means Strongly Agree.

\begin{tabular}{|c|c|c|c|c|c|c|}
\hline 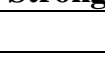 & & SA & $\mathbf{A}$ & $\mathbf{U}$ & DA & SD \\
\hline 1 & على أن يتم تحديد الاحتياجات من الموارد البشرية في ضوء التوجه الاستر اتيجي للشركة & 1 & 2 & 3 & 4 & 5 \\
\hline 2 & 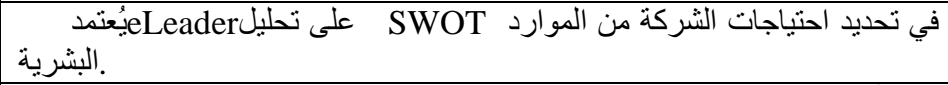 & 1 & 2 & 3 & 4 & 5 \\
\hline 3 & على أن يتم مراجعة تخطبط الموارد البشرية في ضوء تLغير ات بعeader. & 1 & 2 & 3 & 4 & 5 \\
\hline 4 & على أن ينم تخطيط الموارد البشرية مع التخطيط الاستراتيجي على مستوى الثركة & 1 & 2 & 3 & 4 & 5 \\
\hline 5 & 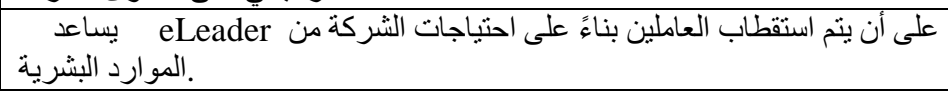 & 1 & 2 & 3 & 4 & 5 \\
\hline 6 & . على أن يستند استقطاب العاملين إلى معايير موضو عية eLeader بساعد. & 1 & 2 & 3 & 4 & 5 \\
\hline 7 & 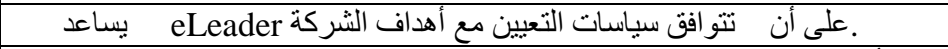 & 1 & 2 & 3 & 4 & 5 \\
\hline 8 & 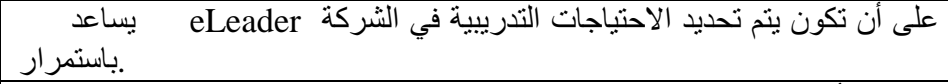 & 1 & 2 & 3 & 4 & 5 \\
\hline 9 & 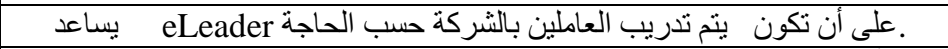 & 1 & 2 & 3 & 4 & 5 \\
\hline 10 & على أن يرتبط منح العاملين الحو افز و المكافآت بمستويات eLeader أدائهم الوظيفي & 1 & 2 & 3 & 4 & 5 \\
\hline
\end{tabular}




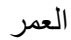

الخبرة

Findings of the Study:-

The following tables show the findings of the study. As shown below 164 out of 479 employees are female (34.2 percent).

\begin{tabular}{|c|c|c|c|c|c|}
\hline \multicolumn{6}{|c|}{ Demographics (Gender) } \\
\hline & & Frequency & Percent & Valid Percent & Cumulative Percent \\
\hline \multirow[t]{3}{*}{ Valid } & Female & 164 & 34.2 & 34.2 & 34.2 \\
\hline & Male & 315 & 65.8 & 65.8 & 100.0 \\
\hline & Total & 479 & 100.0 & 100.0 & \\
\hline
\end{tabular}

Demographics

(Gender)

Female

Male

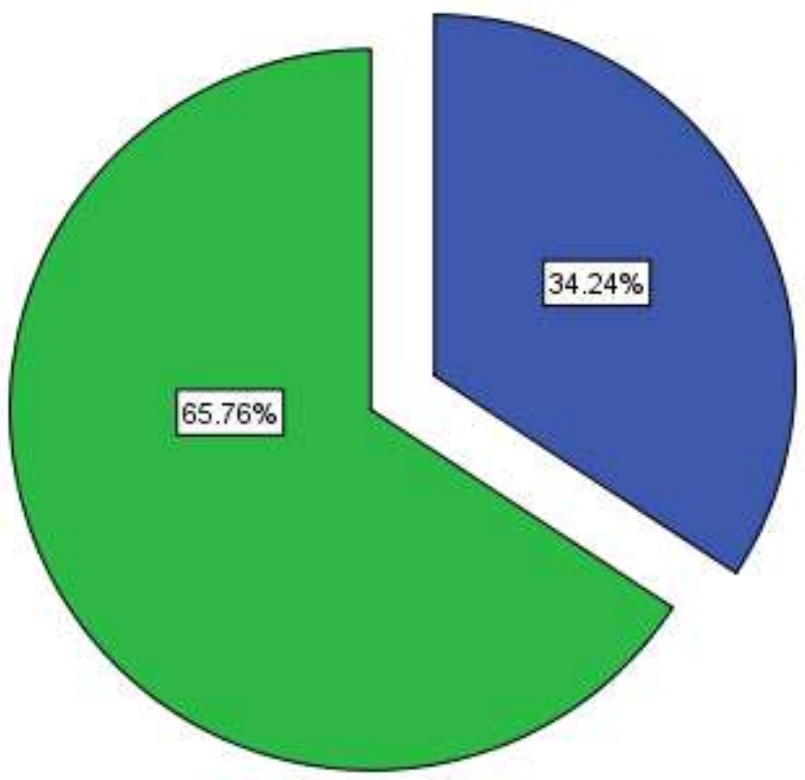

The distribution of age is almost normal with an average age of 34 years.

\begin{tabular}{|l|l|l|}
\hline \multicolumn{2}{|l|}{ Statistics } \\
\hline Demographics (Age of respondent) & Valid & 494 \\
\hline $\mathrm{N}$ & Missing & 0 \\
\hline Mean & 35.2085 \\
\hline Median & 34.0000 \\
\hline Mode & 44.00 \\
\hline Std. Deviation & 9.87585 \\
\hline Skewness & .452 \\
\hline Std. Error of Skewness & .110 \\
\hline Minimum & 19.00 \\
\hline Maximum & 66.00 \\
\hline
\end{tabular}




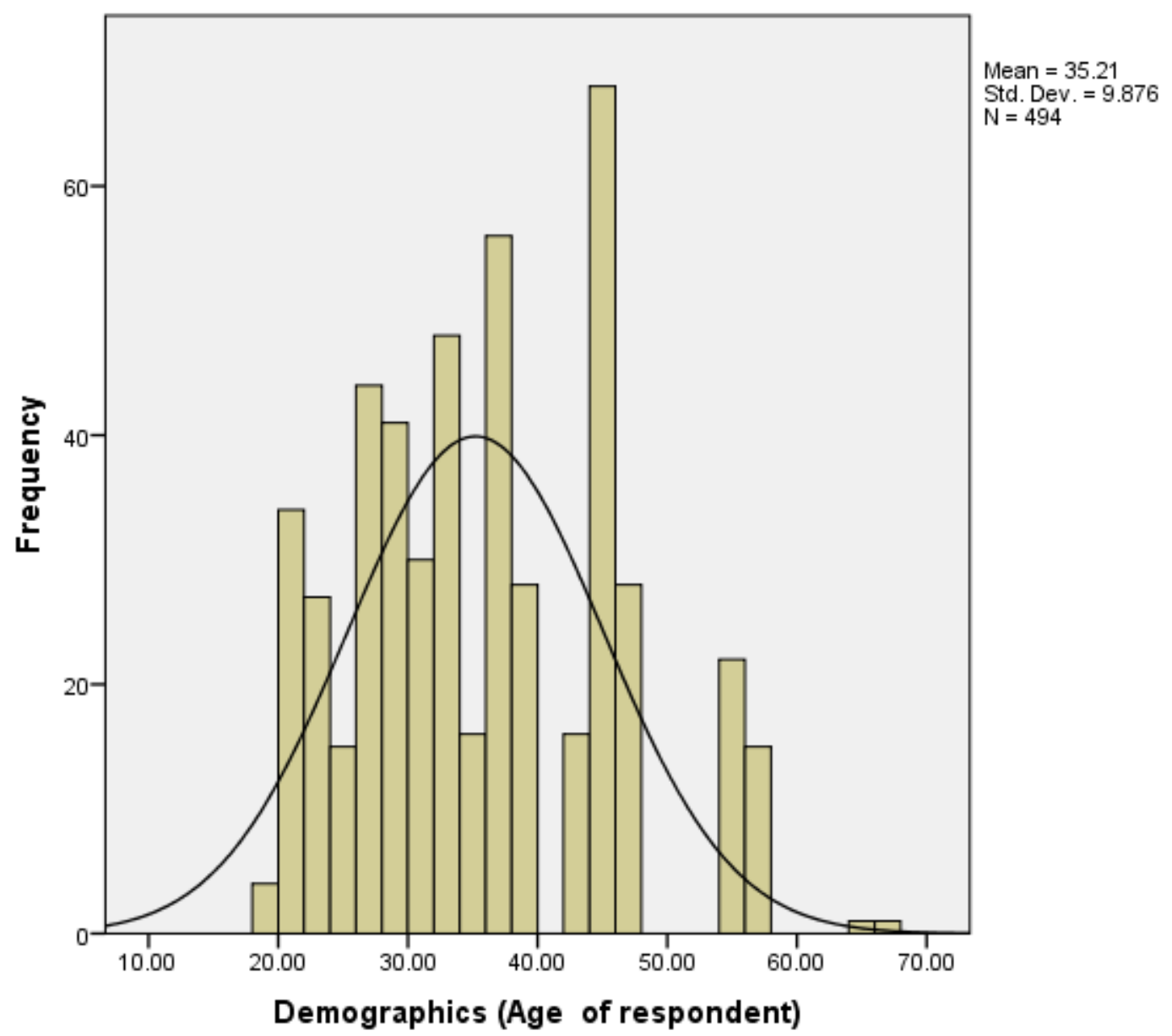

\begin{tabular}{|c|c|c|c|c|c|}
\hline \multicolumn{6}{|c|}{ Demographics (Age of respondent) } \\
\hline & & Frequency & Percent & Valid Percent & Cumulative Percent \\
\hline \multirow[t]{21}{*}{ Valid } & 19.00 & 4 & .8 & .8 & .8 \\
\hline & 20.00 & 16 & 3.2 & 3.2 & 4.0 \\
\hline & 21.00 & 18 & 3.6 & 3.6 & 7.7 \\
\hline & 22.00 & 13 & 2.6 & 2.6 & 10.3 \\
\hline & 23.00 & 14 & 2.8 & 2.8 & 13.2 \\
\hline & 24.00 & 9 & 1.8 & 1.8 & 15.0 \\
\hline & 25.00 & 6 & 1.2 & 1.2 & 16.2 \\
\hline & 26.00 & 24 & 4.9 & 4.9 & 21.1 \\
\hline & 27.00 & 20 & 4.0 & 4.0 & 25.1 \\
\hline & 28.00 & 9 & 1.8 & 1.8 & 26.9 \\
\hline & 29.00 & 32 & 6.5 & 6.5 & 33.4 \\
\hline & 30.00 & 30 & 6.1 & 6.1 & 39.5 \\
\hline & 32.00 & 16 & 3.2 & 3.2 & 42.7 \\
\hline & 33.00 & 32 & 6.5 & 6.5 & 49.2 \\
\hline & 34.00 & 16 & 3.2 & 3.2 & 52.4 \\
\hline & 36.00 & 28 & 5.7 & 5.7 & 58.1 \\
\hline & 37.00 & 28 & 5.7 & 5.7 & 63.8 \\
\hline & 38.00 & 28 & 5.7 & 5.7 & 69.4 \\
\hline & 43.00 & 16 & 3.2 & 3.2 & 72.7 \\
\hline & 44.00 & 36 & 7.3 & 7.3 & 80.0 \\
\hline & 45.00 & 32 & 6.5 & 6.5 & 86.4 \\
\hline
\end{tabular}




\begin{tabular}{|c|c|c|c|c|c|}
\hline & 46.00 & 28 & 5.7 & 5.7 & 92.1 \\
\hline & 55.00 & 22 & 4.5 & 4.5 & 96.6 \\
\hline & 56.00 & 15 & 3.0 & 3.0 & 99.6 \\
\hline & 65.00 & 1 & .2 & .2 & 99.8 \\
\hline & 66.00 & 1 & .2 & .2 & 100.0 \\
\hline & Total & 494 & 100.0 & 100.0 & \\
\hline
\end{tabular}

Moreover, the distribution of experience is almost normally distributed too with an average of 7 years of experience.

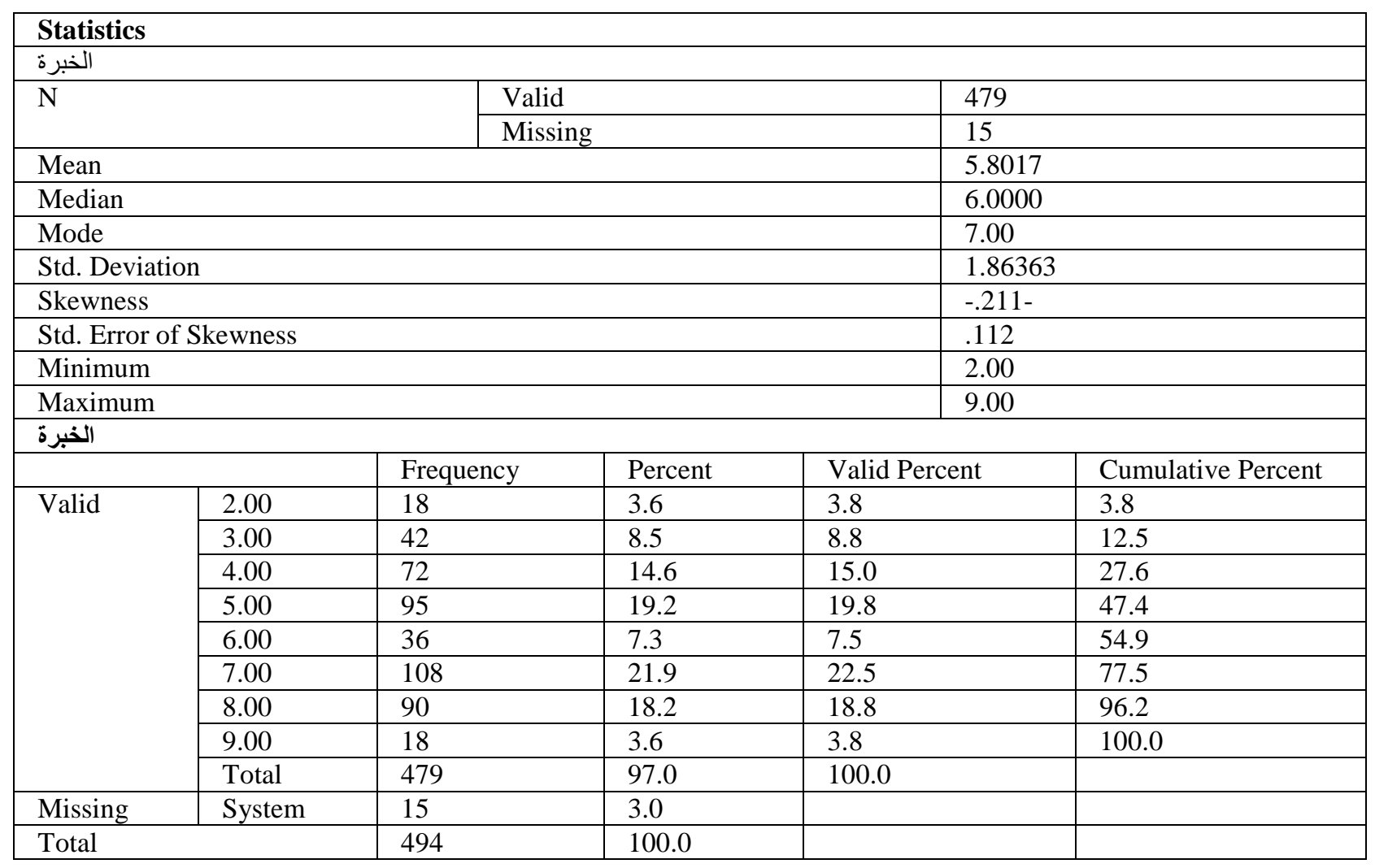




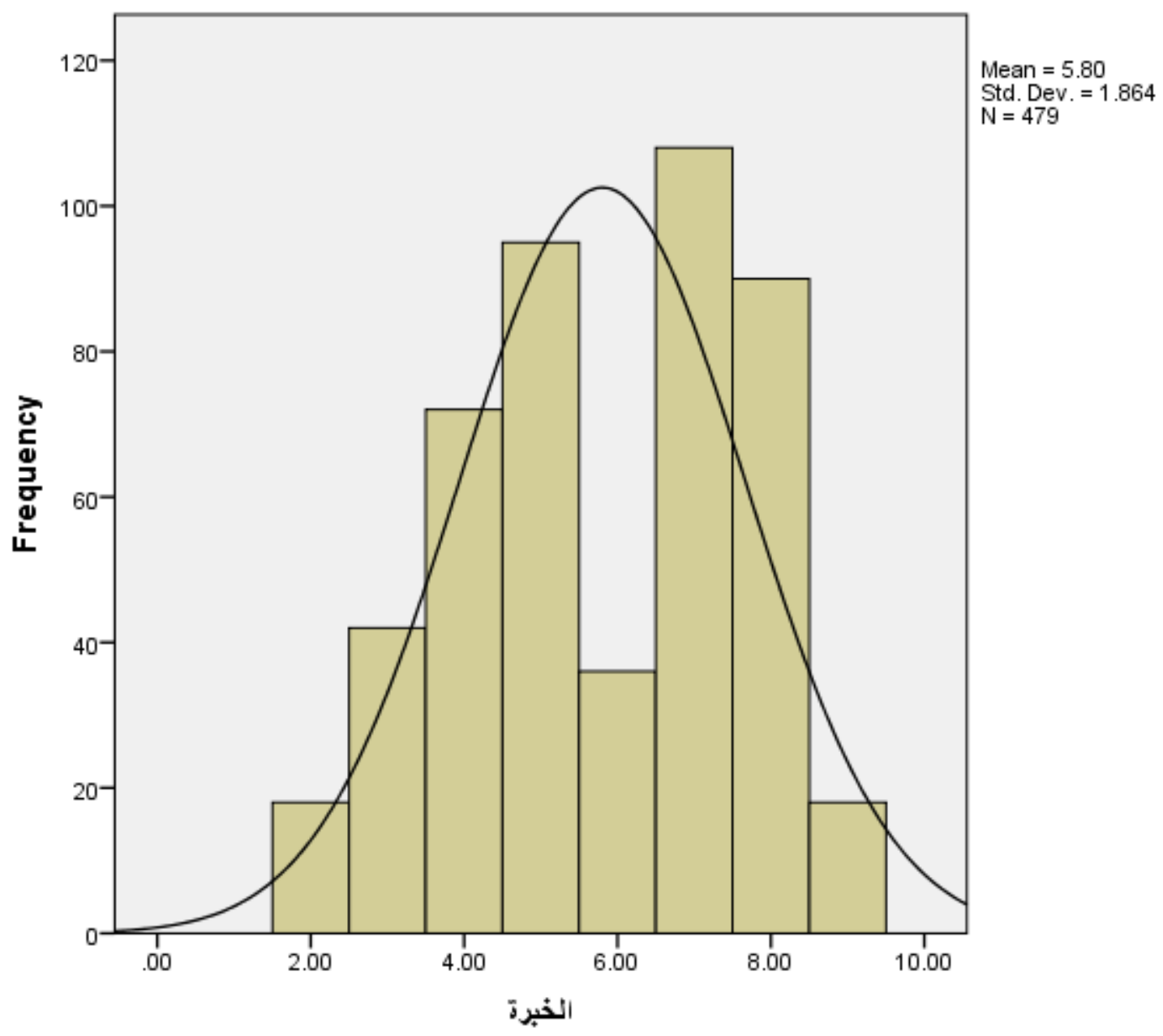

When employees where asked:-

للثركة الاستر اتيجي التوجه ضوء في البشرية الموارد من الاحتياجات تحديد يتم أن على eLeader $\quad$ يساعد

Two thirds disagree with the statement:-

\begin{tabular}{|c|c|c|c|c|c|}
\hline \multirow[t]{2}{*}{ يساعد } & \multicolumn{5}{|c|}{ للثركة الاستر اتيجي التوجه ضوء في البشرية الموارد من الاحتياجات تحديد يتم أن على eLeader } \\
\hline & & Frequency & Percent & Valid Percent & Cumulative Percent \\
\hline \multirow[t]{6}{*}{ Valid } & SD & 160 & 32.4 & 33.7 & 33.7 \\
\hline & $\mathrm{D}$ & 155 & 31.4 & 32.6 & 66.3 \\
\hline & $?$ & 68 & 13.8 & 14.3 & 80.6 \\
\hline & A & 86 & 17.4 & 18.1 & 98.7 \\
\hline & SA & 6 & 1.2 & 1.3 & 100.0 \\
\hline & Total & 475 & 96.2 & 100.0 & \\
\hline Missing & System & 19 & 3.8 & & \\
\hline \multicolumn{2}{|l|}{ Total } & 494 & 100.0 & & \\
\hline
\end{tabular}

\begin{tabular}{|c|c|c|}
\hline \multicolumn{3}{|l|}{ Statistics } \\
\hline يساعد & لاحتياجات ت & للشركة الاستراتيجي التوجة \\
\hline \multirow{2}{*}{$\mathrm{N}$} & Valid & 475 \\
\hline & Missing & 19 \\
\hline \multicolumn{2}{|l|}{ Mean } & 2.2063 \\
\hline \multicolumn{2}{|l|}{ Median } & 2.0000 \\
\hline \multicolumn{2}{|l|}{ Mode } & 1.00 \\
\hline
\end{tabular}




\begin{tabular}{|l|l|}
\hline Std. Deviation & 1.13050 \\
\hline Skewness & .556 \\
\hline Std. Error of Skewness & .112 \\
\hline Minimum & 1.00 \\
\hline Maximum & 5.00 \\
\hline
\end{tabular}

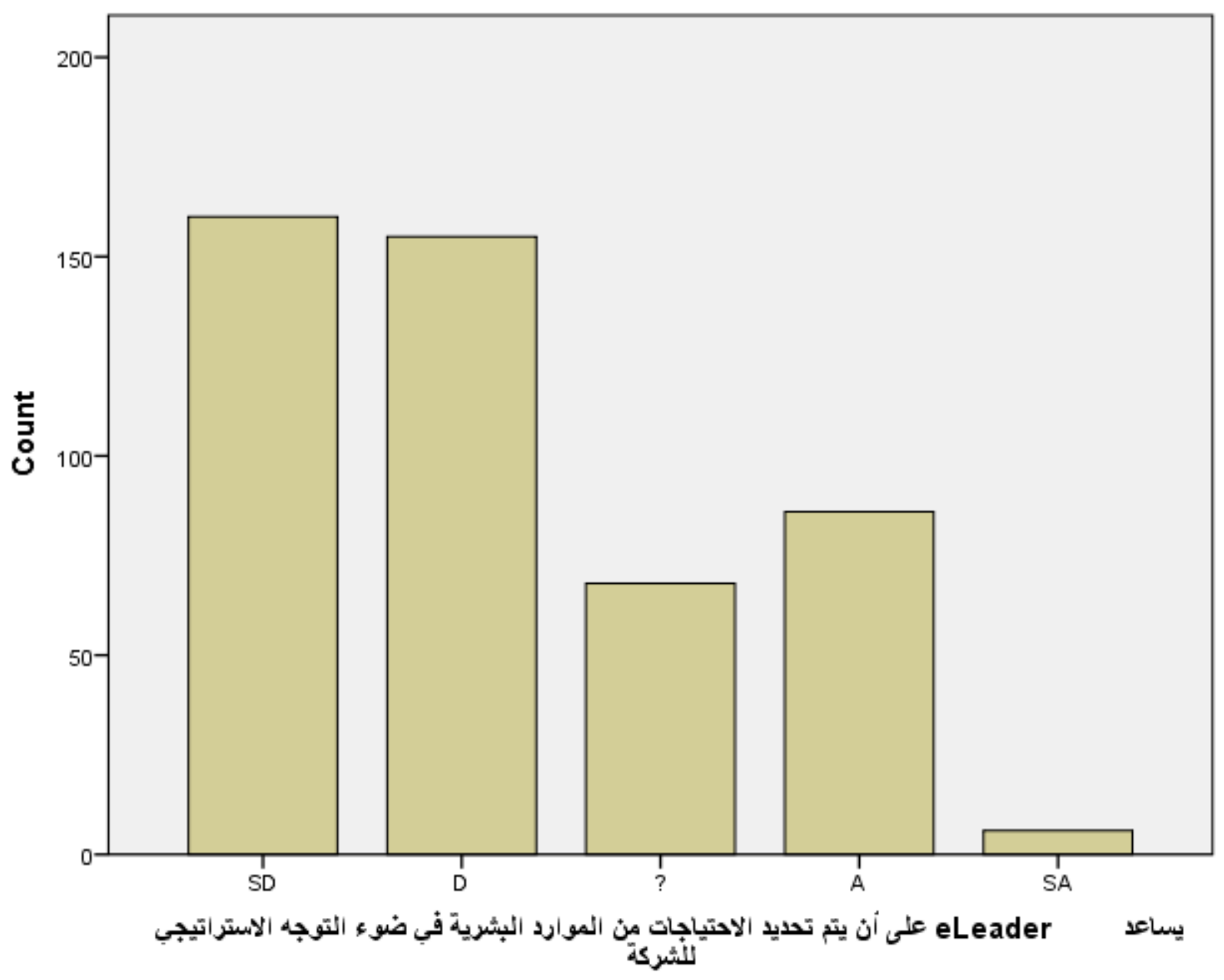

When employees were asked:-

البشرية الموارد من الثركة احتياجات تحديد في SWOT تحليل على Sيُتمد

Almost half of the sample agree with the statement.

\begin{tabular}{|c|c|c|}
\hline \multicolumn{3}{|l|}{ Statistics } \\
\hline ليليل على eLeader يُعتمد & ل كئة احتياجات ذ & \\
\hline \multirow[t]{2}{*}{$\mathrm{N}$} & Valid & 479 \\
\hline & Missing & 15 \\
\hline \multicolumn{2}{|l|}{ Mean } & 3.3967 \\
\hline \multicolumn{2}{|l|}{ Median } & 3.0000 \\
\hline \multicolumn{2}{|l|}{ Mode } & 3.00 \\
\hline \multicolumn{2}{|l|}{ Std. Deviation } & 1.03761 \\
\hline \multicolumn{2}{|l|}{ Skewness } & $-.095-$ \\
\hline \multicolumn{2}{|l|}{ Std. Error of Skewness } & .112 \\
\hline \multicolumn{2}{|l|}{ Minimum } & 1.00 \\
\hline \multicolumn{2}{|l|}{ Maximum } & 5.00 \\
\hline
\end{tabular}




\begin{tabular}{|c|c|c|c|c|c|}
\hline \multicolumn{6}{|c|}{ Cيُعتمد eLeader تحليل على SWOT البشرية الموارد من الثركة احتياجات تحديد في. } \\
\hline & & Frequency & Percent & Valid Percent & Cumulative Percent \\
\hline \multirow[t]{6}{*}{ Valid } & SD & 10 & 2.0 & 2.1 & 2.1 \\
\hline & $\mathrm{D}$ & 93 & 18.8 & 19.4 & 21.5 \\
\hline & ? & 150 & 30.4 & 31.3 & 52.8 \\
\hline & A & 149 & 30.2 & 31.1 & 83.9 \\
\hline & SA & 77 & 15.6 & 16.1 & 100.0 \\
\hline & Total & 479 & 97.0 & 100.0 & \\
\hline Missing & System & 15 & 3.0 & & \\
\hline Total & & 494 & 100.0 & & \\
\hline
\end{tabular}

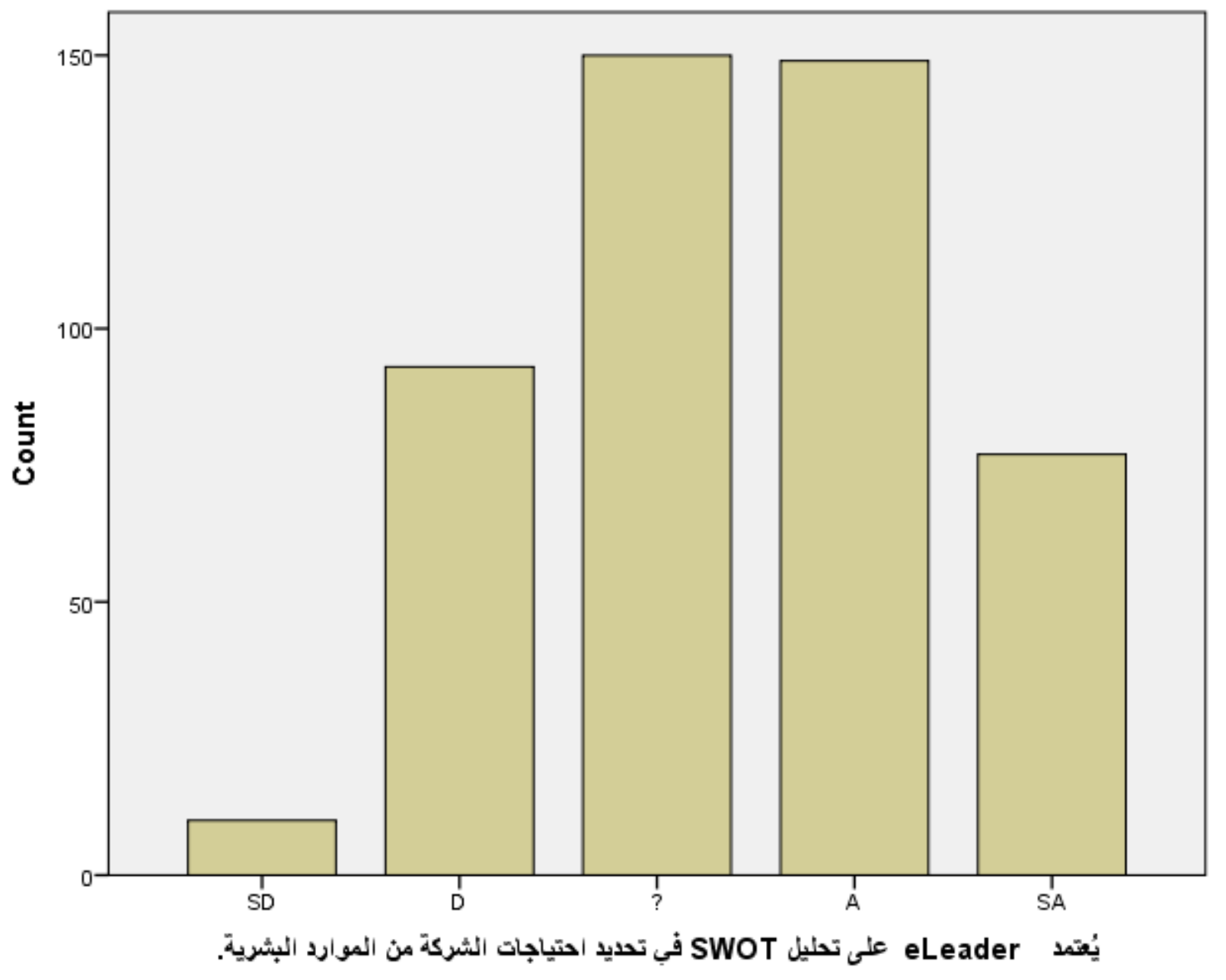

When employees were asked:-

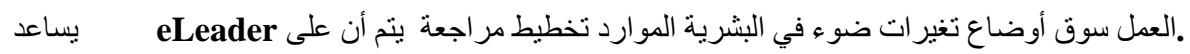

More than one third agree with the statement. 


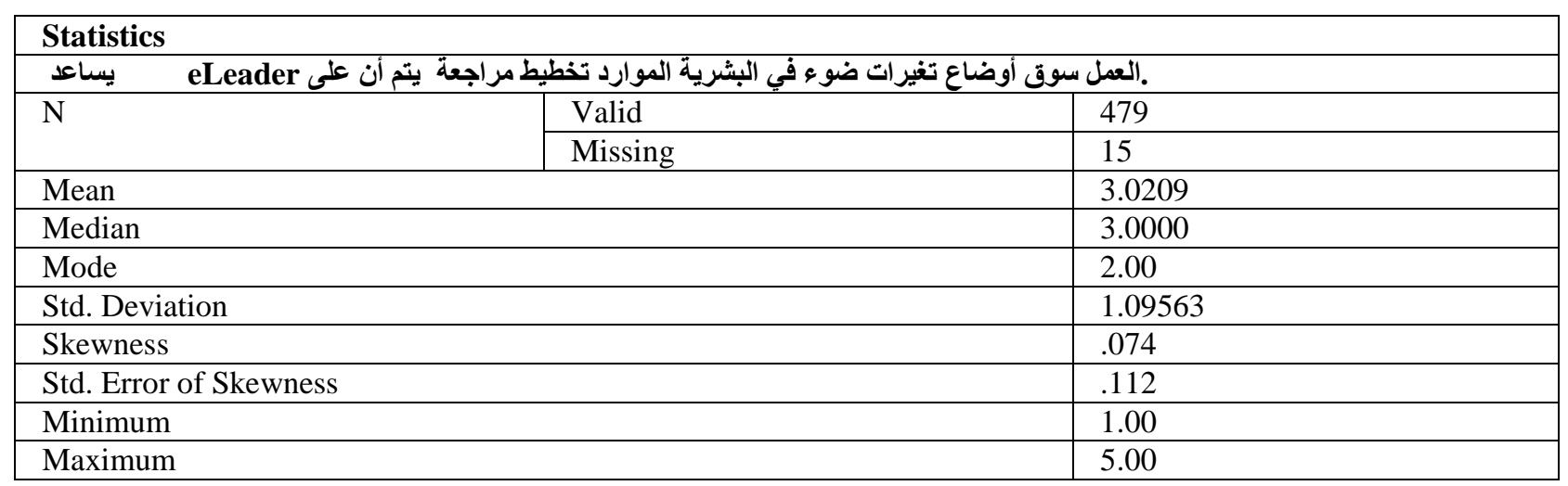

\begin{tabular}{|c|c|c|c|c|c|}
\hline \multirow[t]{2}{*}{ يساعد } & \multicolumn{5}{|c|}{ eLeader العمل سوق أوضاع تغيرات ضوء في البشرية الموارد تخطيط مراجعة يتم أن على. } \\
\hline & & Frequency & Percent & Valid Percent & Cumulative Percent \\
\hline \multirow[t]{6}{*}{ Valid } & SD & 31 & 6.3 & 6.5 & 6.5 \\
\hline & $\mathrm{D}$ & 146 & 29.6 & 30.5 & 37.0 \\
\hline & $?$ & 127 & 25.7 & 26.5 & 63.5 \\
\hline & A & 132 & 26.7 & 27.6 & 91.0 \\
\hline & SA & 43 & 8.7 & 9.0 & 100.0 \\
\hline & Total & 479 & 97.0 & 100.0 & \\
\hline Missing & System & 15 & 3.0 & & \\
\hline Total & & 494 & 100.0 & & \\
\hline
\end{tabular}

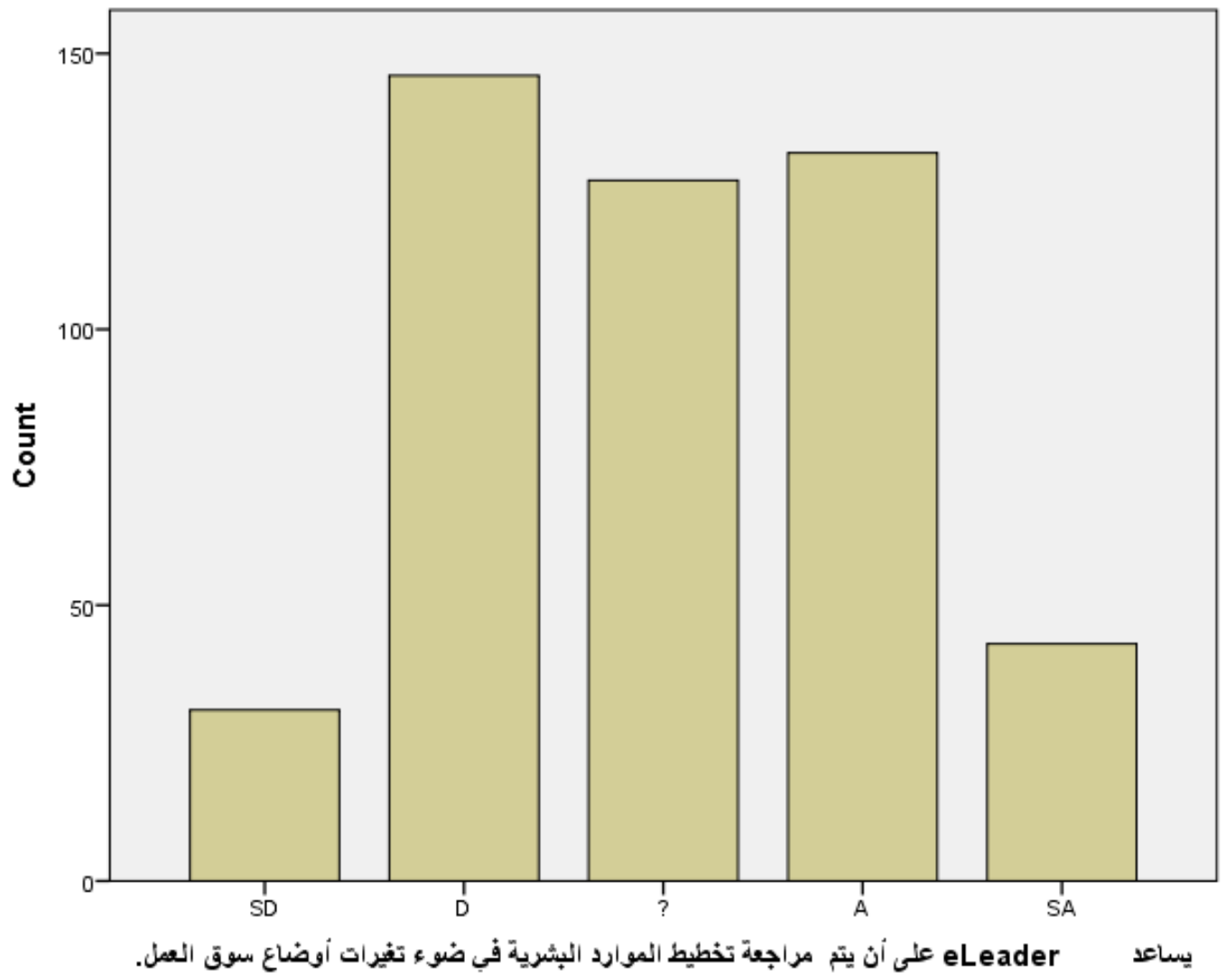


When employees were asked:-

. الثركة مستوى على الاستر اتيجي التخطيط مع البشرية المو ارد تخطيط يتم أن على $\quad$ eLeader $\quad$ يساعد.

Less than half of respondents disagree with the statement.

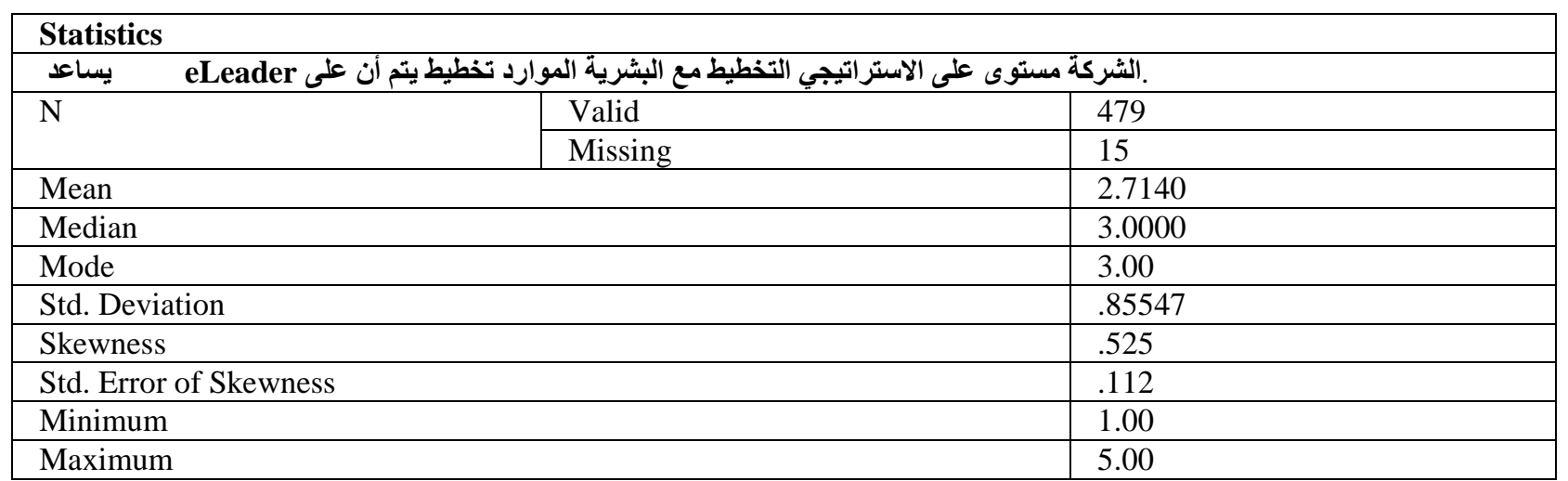

\begin{tabular}{|c|c|c|c|c|c|}
\hline \multirow[t]{2}{*}{ يساعد } & \multicolumn{5}{|c|}{ eLeader الثركة مستوى على الاستراتيجي التخطيط مع البثرية الموارد تخطيط يتم أن على. } \\
\hline & & Frequency & Percent & Valid Percen & Cumulative Percent \\
\hline \multirow[t]{6}{*}{ Valid } & SD & 20 & 4.0 & 4.2 & 4.2 \\
\hline & $\mathrm{D}$ & 186 & 37.7 & 38.8 & 43.0 \\
\hline & $?$ & 201 & 40.7 & 42.0 & 85.0 \\
\hline & A & 55 & 11.1 & 11.5 & 96.5 \\
\hline & SA & 17 & 3.4 & 3.5 & 100.0 \\
\hline & Total & 479 & 97.0 & 100.0 & \\
\hline Missing & System & 15 & 3.0 & & \\
\hline \multicolumn{2}{|l|}{ Total } & 494 & 100.0 & & \\
\hline
\end{tabular}

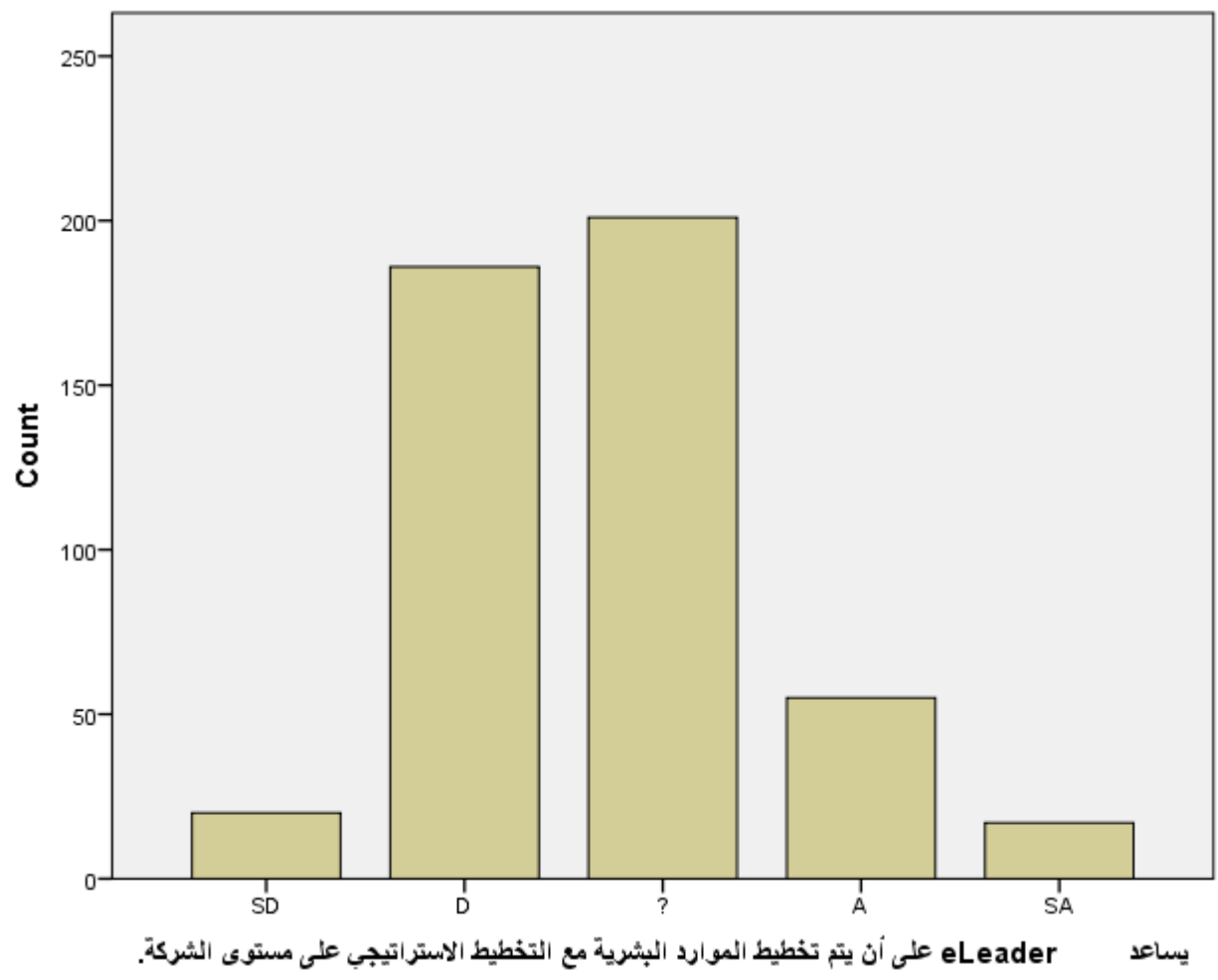


When employees were asked:-

البشرية الموارد من الشركة احتباجات على بناءً العاملين استقطاب ينم أن على eLeader $\quad$ بيساعد.

Almost half of the respondents agree with the statement.

\begin{tabular}{|c|c|c|}
\hline \multicolumn{3}{|l|}{ Statistics } \\
\hline على $\quad$ eLeader $\quad$ يساعد & لمى بناءً العام & \\
\hline \multirow[t]{2}{*}{$\mathrm{N}$} & Valid & 475 \\
\hline & Missing & 19 \\
\hline \multicolumn{2}{|l|}{ Mean } & 3.5474 \\
\hline \multicolumn{2}{|l|}{ Median } & 4.0000 \\
\hline \multicolumn{2}{|l|}{ Mode } & 4.00 \\
\hline \multicolumn{2}{|l|}{ Std. Deviation } & .87353 \\
\hline \multicolumn{2}{|l|}{ Skewness } & $-.680-$ \\
\hline \multicolumn{2}{|l|}{ Std. Error of Skewness } & .112 \\
\hline \multicolumn{2}{|l|}{ Minimum } & 1.00 \\
\hline \multicolumn{2}{|l|}{ Maximum } & 5.00 \\
\hline
\end{tabular}

\begin{tabular}{|c|c|c|c|c|c|}
\hline \multirow[t]{2}{*}{ يساعد } & \multicolumn{5}{|c|}{ eLeader البشرية الموارد من الشركة احتياجات على بناءً العاملين استقطاب يتم أن على. } \\
\hline & & Frequency & Percent & Valid Percent & Cumulative Percent \\
\hline \multirow[t]{6}{*}{ Valid } & SD & 17 & 3.4 & 3.6 & 3.6 \\
\hline & $\mathrm{D}$ & 21 & 4.3 & 4.4 & 8.0 \\
\hline & $?$ & 172 & 34.8 & 36.2 & 44.2 \\
\hline & A & 215 & 43.5 & 45.3 & 89.5 \\
\hline & SA & 50 & 10.1 & 10.5 & 100.0 \\
\hline & Total & 475 & 96.2 & 100.0 & \\
\hline Missing & System & 19 & 3.8 & & \\
\hline \multicolumn{2}{|l|}{ Total } & 494 & 100.0 & & \\
\hline
\end{tabular}

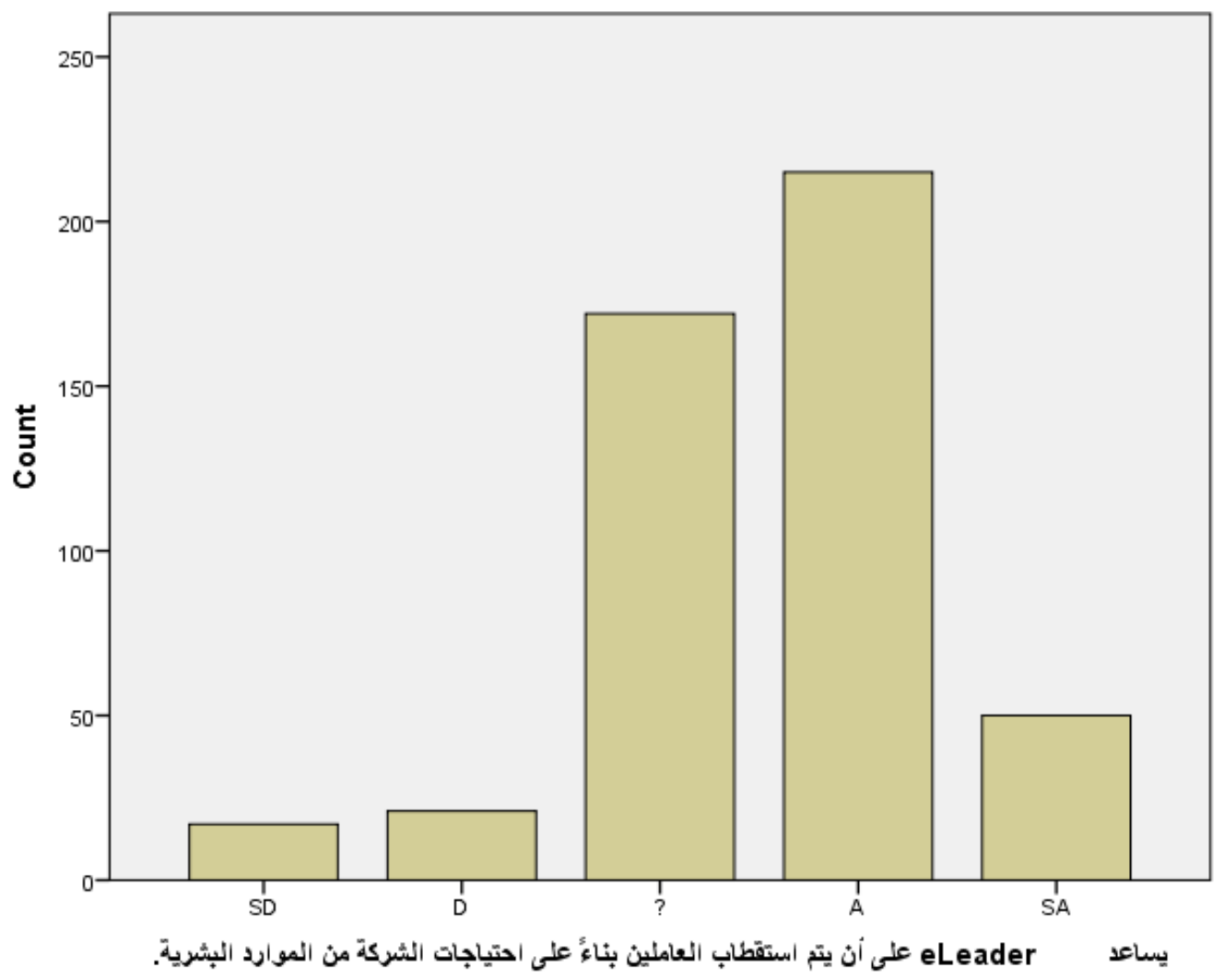


When employees were asked:

موضو عية معايير إلى العاملين استقطاب بيتند أن على بيساعد. $\quad$ eLeader.

One third disagree with the statement.

\begin{tabular}{|c|c|c|}
\hline \multicolumn{3}{|l|}{ Statistics } \\
\hline أن على eLeader & موضو عية معايير إلى العاملين استقطاب يستند & \\
\hline \multirow[t]{2}{*}{$\mathrm{N}$} & \begin{tabular}{l|l} 
& Valid \\
\end{tabular} & 479 \\
\hline & Missing & 15 \\
\hline Mean & & 2.8038 \\
\hline Median & & 3.0000 \\
\hline Mode & & 3.00 \\
\hline Std. Deviation & & .90738 \\
\hline Skewness & & .043 \\
\hline Std. Error of Skewness & & .112 \\
\hline Minimum & & 1.00 \\
\hline Maximum & & 5.00 \\
\hline
\end{tabular}

\begin{tabular}{|c|c|c|c|c|c|}
\hline \multirow[t]{2}{*}{ يساعد } & \multicolumn{5}{|c|}{ eLeader موضوعية معايير إلى العاملين استقطاب يستند أن على. } \\
\hline & & Frequency & Percent & Valid Percent & Cumulative Percent \\
\hline \multirow[t]{6}{*}{ Valid } & SD & 44 & 8.9 & 9.2 & 9.2 \\
\hline & $\mathrm{D}$ & 98 & 19.8 & 20.5 & 29.6 \\
\hline & $?$ & 268 & 54.3 & 55.9 & 85.6 \\
\hline & A & 46 & 9.3 & 9.6 & 95.2 \\
\hline & SA & 23 & 4.7 & 4.8 & 100.0 \\
\hline & Total & 479 & 97.0 & 100.0 & \\
\hline Missing & System & 15 & 3.0 & & \\
\hline \multicolumn{2}{|l|}{ Total } & 494 & 100.0 & & \\
\hline
\end{tabular}

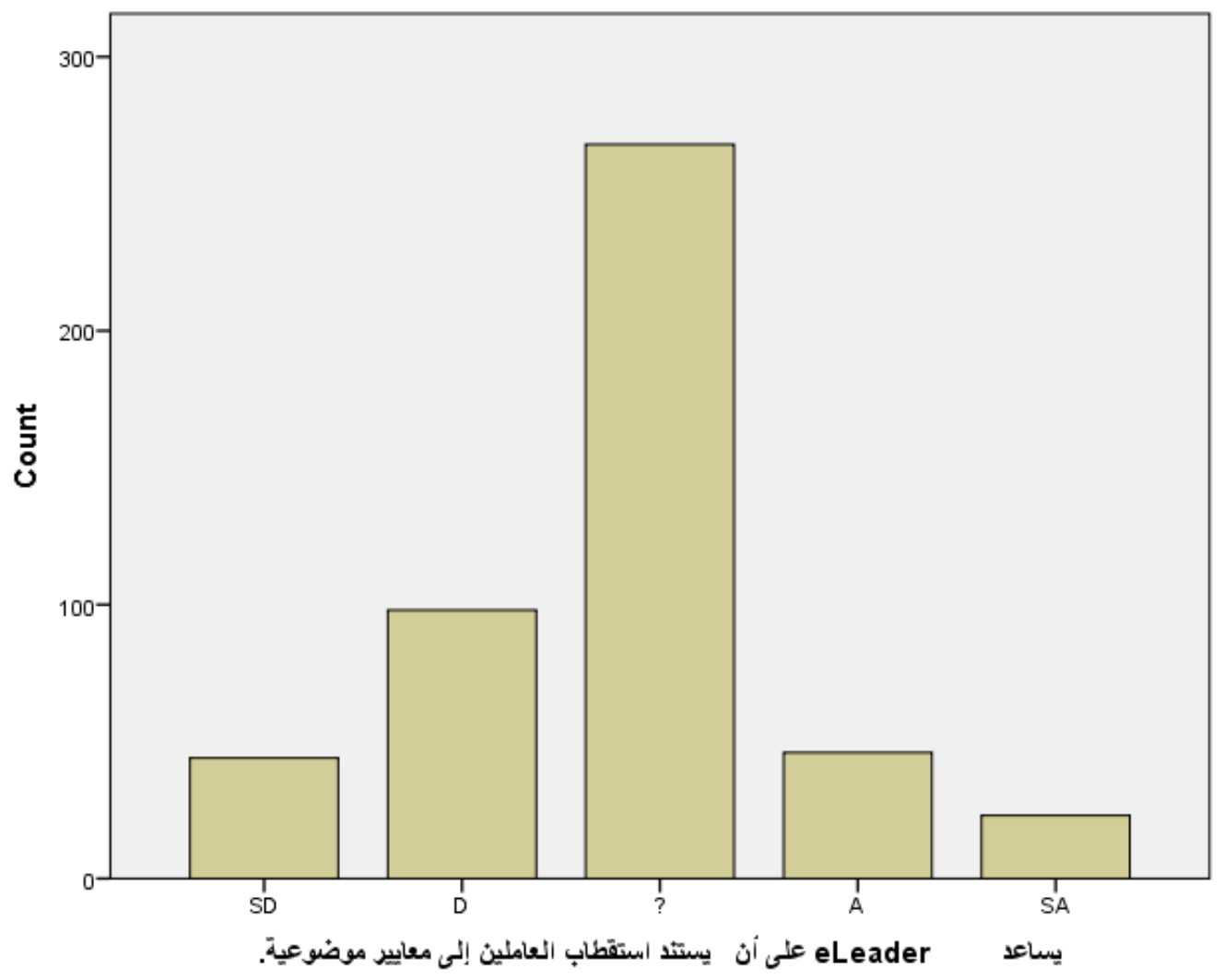


When employees were asked:

الثركة أهداف مع التعيين سياسات تتو افق أن على eLeader $\quad$ يساعد

One third disagree with the statement.

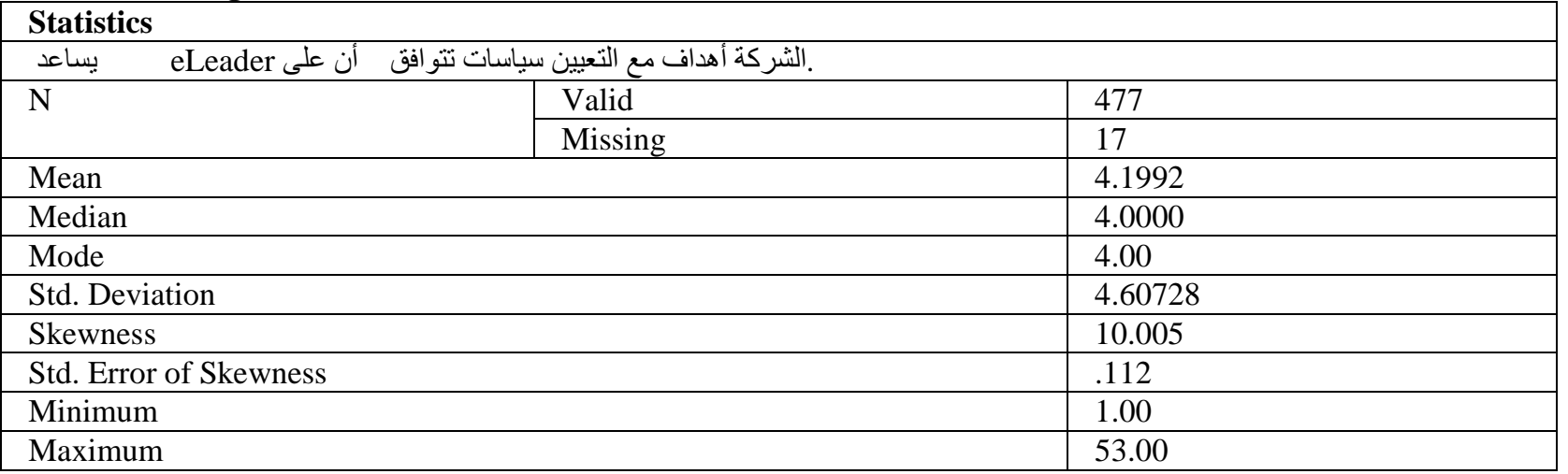

\begin{tabular}{|c|c|c|c|c|c|}
\hline \multirow{2}{*}{ 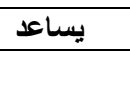 } & \multicolumn{5}{|c|}{ eLeader الثركة أهداف مع التعيين سياسات تتوافق أن على. } \\
\hline & & Frequency & Percent & Valid Percent & Cumulative Percent \\
\hline \multirow{7}{*}{ Valid } & SD & 13 & 2.6 & 2.7 & 2.7 \\
\hline & $\mathrm{D}$ & 53 & 10.7 & 11.1 & 13.8 \\
\hline & $?$ & 73 & 14.8 & 15.3 & 29.1 \\
\hline & A & 217 & 43.9 & 45.5 & 74.6 \\
\hline & SA & 117 & 23.7 & 24.5 & 99.2 \\
\hline & 53.00 & 4 & .8 & .8 & 100.0 \\
\hline & Total & 477 & 96.6 & 100.0 & \\
\hline Missing & System & 17 & 3.4 & & \\
\hline \multicolumn{2}{|l|}{ Total } & 494 & 100.0 & & \\
\hline
\end{tabular}

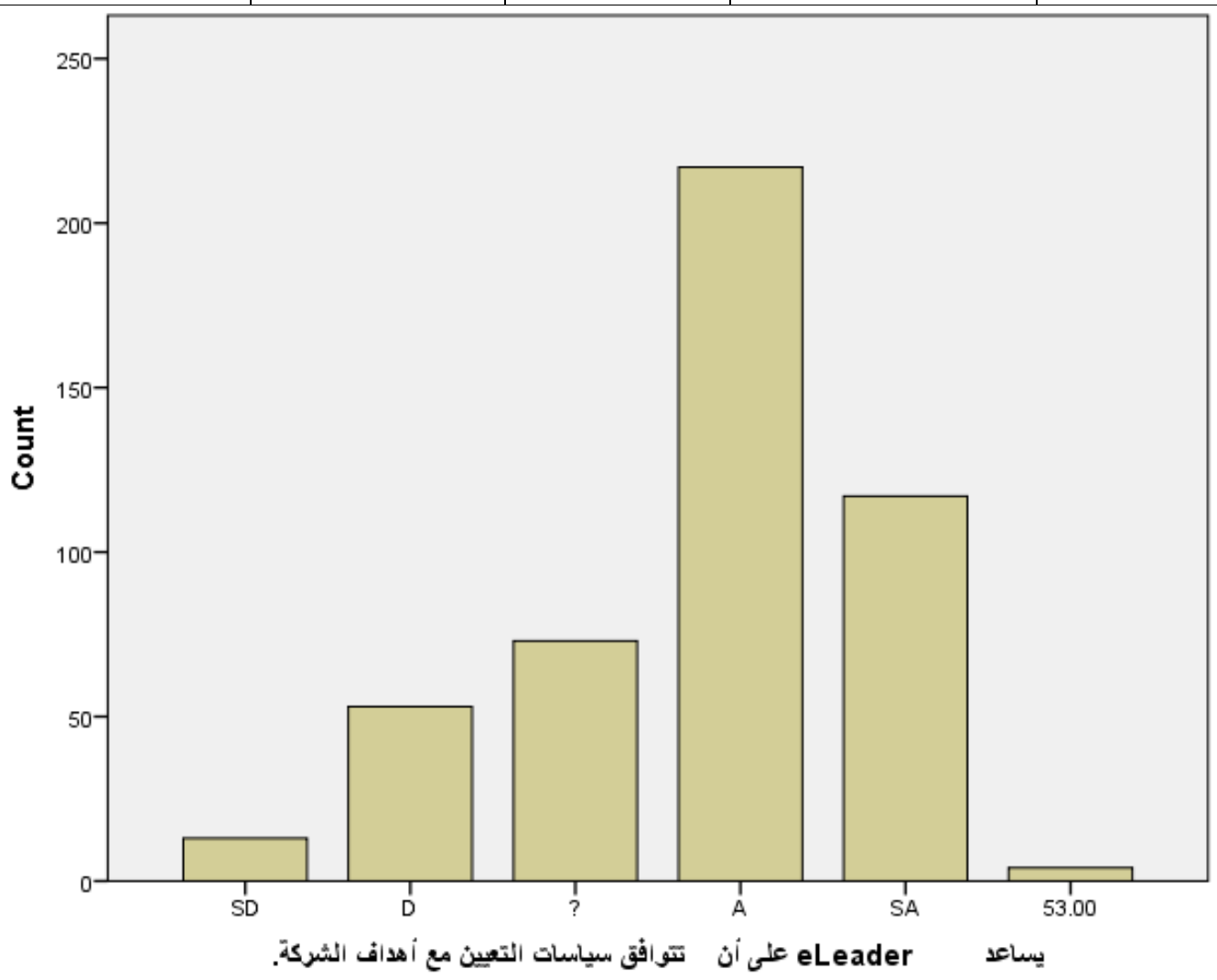


When employees were asked:

باستمر ار الثركة في التدريبية الاحتياجات تحديد يتم تكون أن على eLeader $\quad$ يساعد

Two thirds disagree with the statement.

Statistics

\begin{tabular}{|l|l|l|}
\hline \multicolumn{2}{|l|}{ eLeader باستمرار الثركة في التدريبية الاحتياجات تحديد يتم تكون أن على } & 477 \\
\hline $\mathrm{N}$ & Valid & 17 \\
\cline { 2 - 3 } & Missing & 3.1468 \\
\hline Mean & 3.0000 \\
\hline Median & 3.00 \\
\hline Mode & 1.00181 \\
\hline Std. Deviation & .156 \\
\hline Skewness & .112 \\
\hline Std. Error of Skewness & 1.00 \\
\hline Minimum & 5.00 \\
\hline Maximum &
\end{tabular}

\begin{tabular}{|c|c|c|c|c|c|}
\hline \multicolumn{6}{|c|}{ eLeader باستمرار الثركة في التدريبية الاحتياجات تحديد يتم تكون أن على. } \\
\hline & & Frequency & Percent & Valid Percent & Cumulative Percent \\
\hline \multirow[t]{6}{*}{ Valid } & SD & 16 & 3.2 & 3.4 & 3.4 \\
\hline & $\mathrm{D}$ & 109 & 22.1 & 22.9 & 26.2 \\
\hline & $?$ & 193 & 39.1 & 40.5 & 66.7 \\
\hline & A & 107 & 21.7 & 22.4 & 89.1 \\
\hline & SA & 52 & 10.5 & 10.9 & 100.0 \\
\hline & Total & 477 & 96.6 & 100.0 & \\
\hline Missing & System & 17 & 3.4 & & \\
\hline \multicolumn{2}{|l|}{ Total } & 494 & 100.0 & & \\
\hline
\end{tabular}

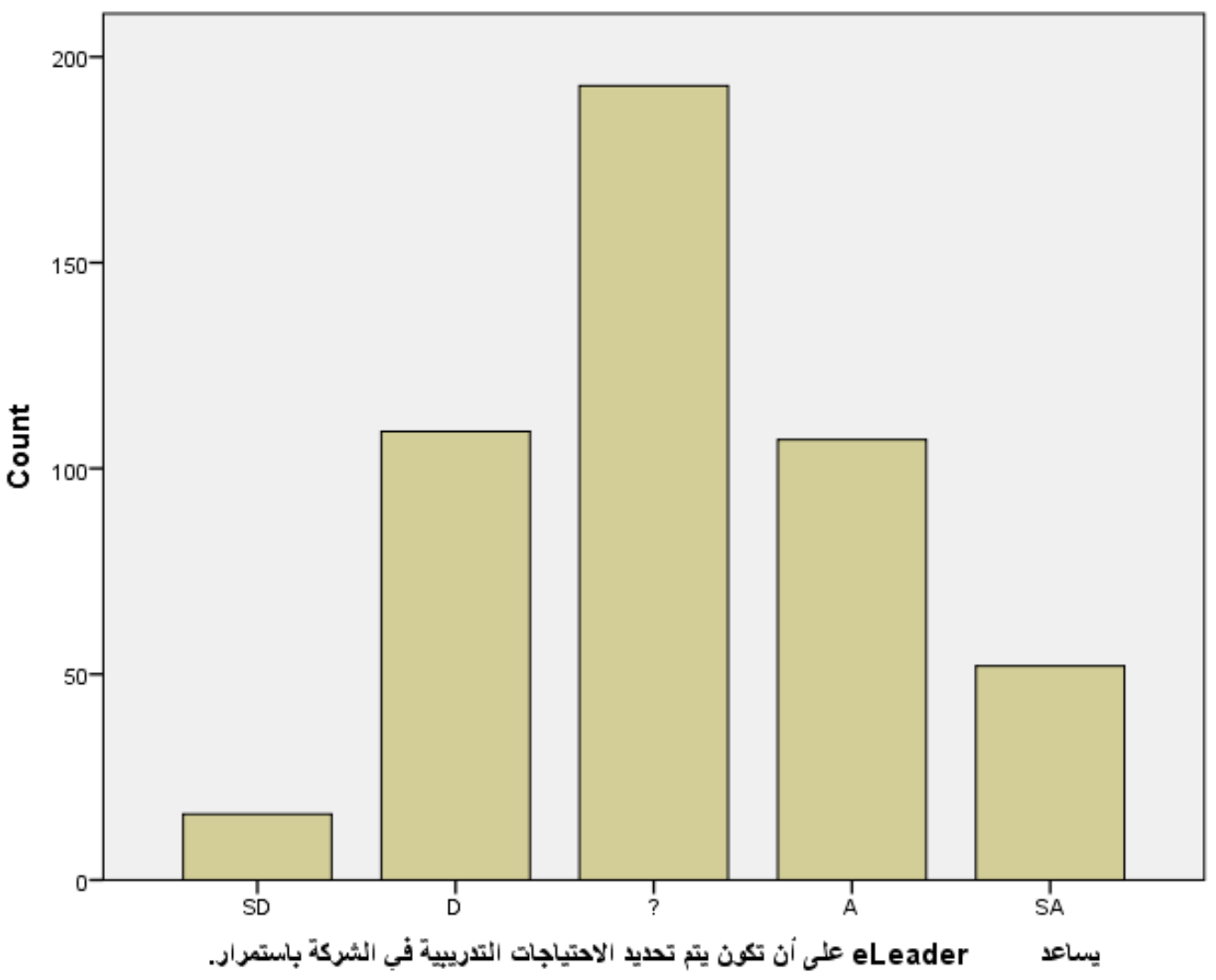


When employees were asked:-

الحاجة حسب بالثركة العاملين تدريب يتم تكون أن على eLeader $\quad$ يساعد.

One quarter of respondents disagree with the statement.

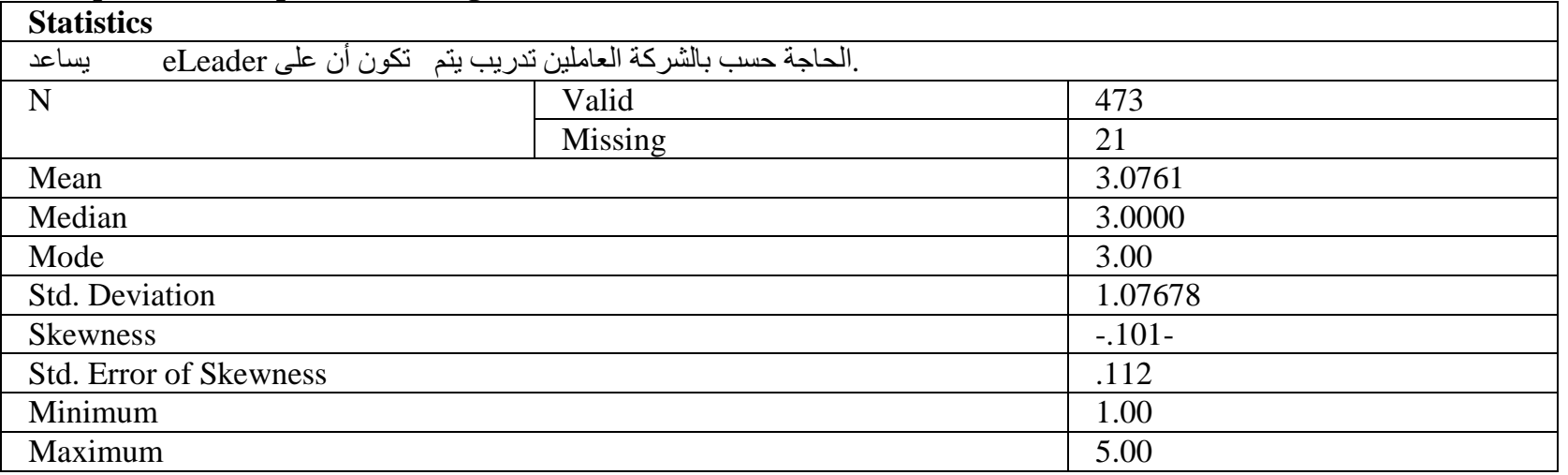

\begin{tabular}{|c|c|c|c|c|c|}
\hline \multirow[t]{2}{*}{ 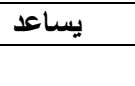 } & \multicolumn{5}{|c|}{ eLeader الحاجة حسب بالثركة العاملين تلريب يتم تكون أن على. } \\
\hline & & Frequency & Percent & Valid Percent & Cumulative Percent \\
\hline \multirow[t]{6}{*}{ Valid } & SD & 38 & 7.7 & 8.0 & 8.0 \\
\hline & $\mathrm{D}$ & 100 & 20.2 & 21.1 & 29.2 \\
\hline & $?$ & 166 & 33.6 & 35.1 & 64.3 \\
\hline & A & 126 & 25.5 & 26.6 & 90.9 \\
\hline & SA & 43 & 8.7 & 9.1 & 100.0 \\
\hline & Total & 473 & 95.7 & 100.0 & \\
\hline Missing & System & 21 & 4.3 & & \\
\hline \multicolumn{2}{|l|}{ Total } & 494 & 100.0 & & \\
\hline
\end{tabular}

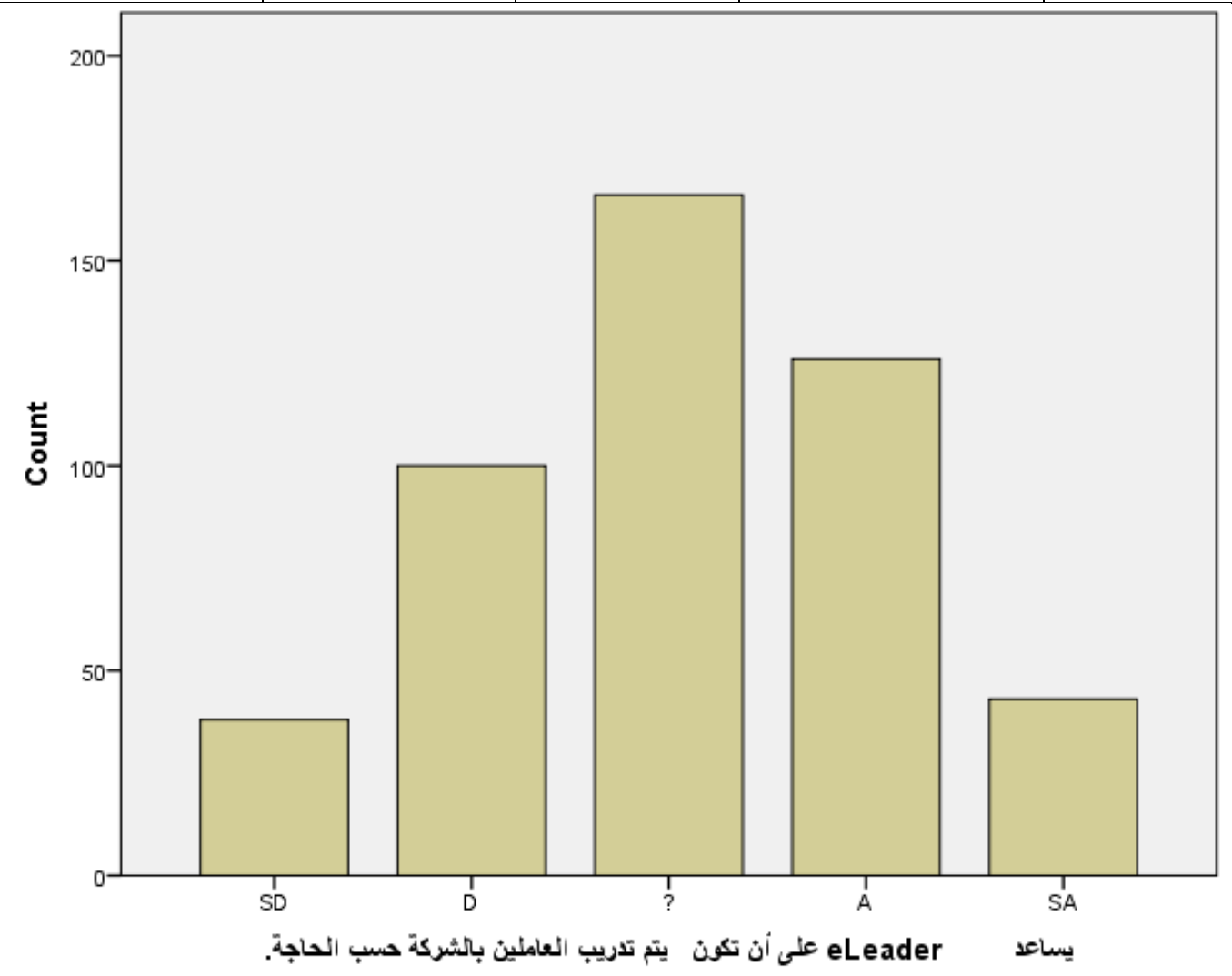


When employees were asked:-

• الوظيفي أدائهم بمستويات و المكافآت الحو افز العاملين منح يرتبط أن على $\quad$ eLeader

Close to a quarter disagree with the statement.

\begin{tabular}{|c|c|c|}
\hline \multicolumn{3}{|l|}{ Statistics } \\
\hline \multicolumn{3}{|c|}{ الوظيفي أدائهم بمستو يات و المكافآت الحو افز العاملين منح يرتبط أن على $\quad$ eLeader. } \\
\hline \multirow[t]{2}{*}{$\mathrm{N}$} & Valid & 477 \\
\hline & Missing & 17 \\
\hline \multicolumn{2}{|l|}{ Mean } & 3.1006 \\
\hline \multicolumn{2}{|l|}{ Median } & 3.0000 \\
\hline \multicolumn{2}{|l|}{ Mode } & 3.00 \\
\hline \multicolumn{2}{|l|}{ Std. Deviation } & 1.02814 \\
\hline \multicolumn{2}{|l|}{ Skewness } & .054 \\
\hline \multicolumn{2}{|l|}{ Std. Error of Skewness } & .112 \\
\hline \multicolumn{2}{|l|}{ Minimum } & 1.00 \\
\hline \multicolumn{2}{|l|}{ Maximum } & 5.00 \\
\hline
\end{tabular}

\begin{tabular}{|c|c|c|c|c|c|}
\hline \multirow[t]{2}{*}{ يساعد } & \multicolumn{5}{|c|}{ الوظيفي أدائهم بمستويات والمكافآت الحوافز العاملين منح يرتبط أن على eLeader. } \\
\hline & & Frequency & Percent & Valid Percent & Cumulative Percent \\
\hline \multirow[t]{6}{*}{ Valid } & SD & 27 & 5.5 & 5.7 & 5.7 \\
\hline & $\mathrm{D}$ & 100 & 20.2 & 21.0 & 26.6 \\
\hline & $?$ & 197 & 39.9 & 41.3 & 67.9 \\
\hline & A & 104 & 21.1 & 21.8 & 89.7 \\
\hline & SA & 49 & 9.9 & 10.3 & 100.0 \\
\hline & Total & 477 & 96.6 & 100.0 & \\
\hline Missing & System & 17 & 3.4 & & \\
\hline \multicolumn{2}{|l|}{ Total } & 494 & 100.0 & & \\
\hline
\end{tabular}

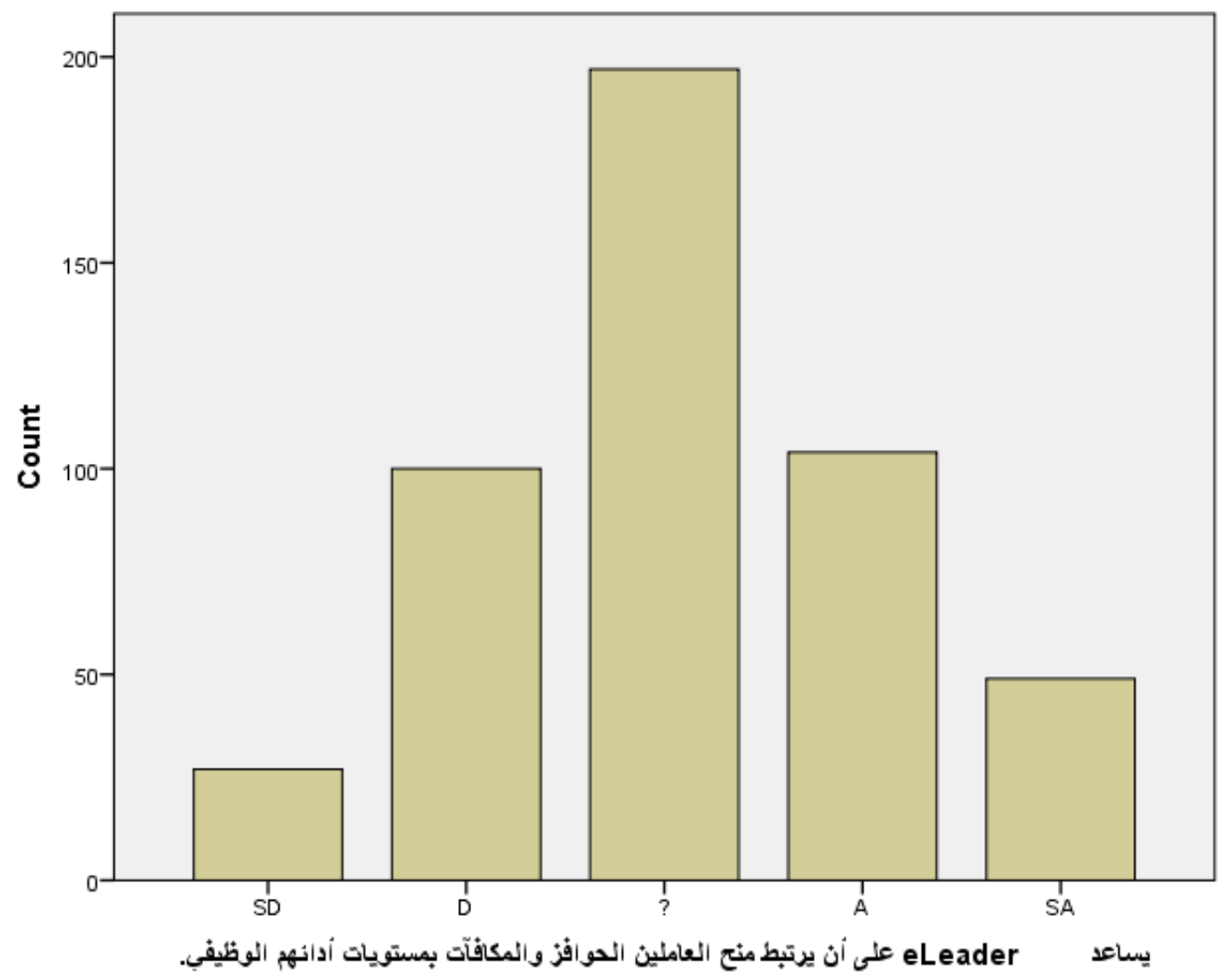




\section{Summary, Conclusion and Recommendation:-}

Findings of the study showed that almost half of the sample of respondents did not agree or disagree with the eleader statements. It seems to me that employees in the Lebanese SMEs don't really understand the skills and functions of e-leader. The e-leader concept seems to be a new phenomenon for employees. The researcher in this study recommends awareness campaign among employees and more research to be conducted in sectors other than SMEs in Lebanon.

\section{References:-}

1. Amabile, T.M. (1988), "A model of creativity and innovation in organizations", in Shaw, B.M. and Cummings, L.L. (Eds), Research in Organizational Behavior,Vol. 10, pp. 123-67.

2. Axtell, C.M., Holman, D.J., Unsworth, K.L., Wall, T.D., Waterson, P.E. and Harrington, E. (2000), "Shopfloor innovation: facilitating the suggestion and implementation of ideas", Journal of Occupational \& Organizational Psychology, Vol. 73, pp. 265-85.

3. Bass, B.M. (1999). Two decades of research and development in transformational leadership.

4. European Journal of Work and Organizational Psychology, Vol 8, No 1, P 9-32

5. Boer, H. and Gieskes, J. (1998), Continuous Improvement - From Idea to Reality, Twente University Press, Enschede.

6. Braczyk, H., Heidenreich, M. and Cooke, P. (1998), Regional Innovation Systems: The Role of

7. Governance in a Globalised World, UCL Press, London.

8. Chen, J.C. \& Silverthorne, C. (2005). Leadership effectiveness, leadership style and employee readiness. Leadership \& Organization Development Journal, Vol 26, No 4, P 280-288

9. Crossman, Alf and Abou-Zaki, Bassem. (2003). Job satisfaction and employee performance of Lebanese banking staff. Journal of Managerial Psychology, 368-376.

10. Drucker, P. (1985), Innovation and Entrepreneurship, Macmillan, Basingstoke.

11. Dulewicz, V. \& Higgs, M. (2003). Leadership at the top: The need for emotional intelligence in organizations. International Journal of Organizational Analysis, Vol 11, No 3, P 193-210

12. Ehigie, B.O. and Akpan, R.C. (2004), "Roles of perceived leadership styles and rewards in the practice of total quality management”, Leadership \& Organization Development Journal, Vol. 25 No. 1, pp. 24-40.

13. Eskildsen, Jacob K., Kristensen, Kai and Westlund, Anders H. (2003). Work motivation and job satisfaction in the Nordic countries. Employee Relations, 122-136.

14. Furnham, Adrian, Eracleous, Andreas and Chamorro-Premuzic, Tomas. (2009). Personality, motivation and job satisfaction: Hertzberg meets the Big Five. Journal of Managerial Psychology, 765-779.

15. Graham, Michael W. and Messner, Philip E. (1998). Principals and job satisfaction. International Journal of Educational Management, 196-202.

16. Islam, Rafikul and $\mathrm{Hj}$. Ismail, Ahmad Zaki. (2008). Employee motivation: a Malaysian perspective. International Journal of Commerce and Management, 344-362.

17. Jaskyte, K. (2004). Transformational leadership, organizational culture, and innovativeness in nonprofit organizations. Nonprofit Management and Leadership, Vol 15, No 2, P 153-168

18. McLoughlin, I. and Harris, M. (1997), Innovation, Organizational Change and Technology, Thompson, London.

19. Smith, G.P. (2002), "The new leader: bringing creativity and innovation to the workplace", Chart Your Course, Conyers, Georgia.

20. Sahinidis, Alexandros G. and Bouris, John. (2008). Employee perceived training effectiveness relationship to employee attitudes. Journal of European Industrial Training, 63-76.

21. Stringer, Carolyn, Didham, Jeni and Theivananthampillai, Paul. (2011). Motivation, pay satisfaction, and job satisfaction of front-line employees. Qualitative Research in Accounting \&, 161-179.

22. Tietjen, Mark A. and Myers, Robert M. (1988). Motivation and job satisfaction. Management Decision, 226231.

23. Teece, D.J. (1996), "Firm organisation, industrial structure, and technological innovation", Journal of Economic Behaviour and Organisation, Vol. 31, pp. 193-224.

24. Unsworth, K.L. and Parker, S.K. (2003), "Proactivitiy and innovation: promoting a new workforce for the new workplace", in Holman, T., Wall, T.D., Clegg, C.W., Sparrow, P. and Howard, A. (Eds), The New Workplace: A Guide to the Human Impact of Modern Work Practices, Wiley, Chichester, pp. 175-96.

25. Van de Ven, A. (1986), "Central problems in the management of innovation", Management Science, Vol. 32, pp. 590-607. 
26. Princely Ifinedo, (2011) "Internet/e-business technologies acceptance in Canada's SMEs: an exploratory investigation", Internet Research, Vol. 21 Iss: 3, pp.255 - 281 The full text is available at: www.emeraldinsight.com

27. Geoffrey J. Simmons, Mark G. Durkin, Pauric McGowan, Gillian A. Armstrong, (2007) "Determinants of internet adoption by SME Agri-food companies" Journal of Small Business and Enterprise Development Volume: 14 Issue: 42007 The full text is available at: www.emeraldinsight.com

28. Joel Indrupati and Tara Henari, 2010, "Entrepreneurial success, using online social networking: evaluation" USEconomy - Gulf Cooperation Council, About.US.com. The full text is available at: www.emeraldinsight.com

29. Nancy M. Levenburg (2006) "Benchmarking customer service on the internet: best practices from family businesses" Benchmarking: An International Journal Volume: 13 Issue: 32006 The full text is available at: www.emeraldinsight.com

30. Gunasekaran, E.W.T. Ngai (2005) “ E-commerce in Hong Kong: an empirical perspective and analysis” Internet Research Volume: 15 Issue: 22005 The full text is available at: www.emeraldinsight.com

31. Ismail Sila, Dawn Dobni, (2012) "Patterns of B2B e-commerce usage in SMEs", Industrial Management \& Data Systems, Vol. 112 Iss: 8, pp.1255 - 1271 The full text is available at: www.emeraldinsight.com. 